\title{
Perceptions of land managers towards using hybrid and genetically modified trees
}

\author{
Andrea N. Brennan ${ }^{1,2} \mathbb{D} \cdot$ Zhao Ma $^{1} \cdot$ Douglass F. Jacobs ${ }^{1}$
}

Received: 20 April 2021 / Accepted: 8 November 2021

(c) The Author(s) 2021

\begin{abstract}
Hybridization and genetic modification are potential methods for incorporation of stress tolerance being explored to support some at-risk tree species. However, many concerns, both ecological and economic, have been identified in using these biotechnologies, such as potential for invasiveness or high cost. There is limited information on perceptions towards hybrid and genetically modified (GM) trees, particularly from individuals responsible for widescale tree management. An online survey was administered to land managers in Indiana, USA to gauge perceptions to hybrid and GM trees, and current hybrid tree use. Land managers had stronger concern for ecological, rather than economic, issues, with potential for invasiveness being strongest. Agreement was highest for using the tree types for conservation and restoration of at-risk species and production purposes. However, perceptions varied by characteristics such as concern type, age, and land type managed. Ecological concern and land type managed most strongly predicted hybrid use. Overall, the majority of land managers agreed, rather than disagreed, with a variety of potential hybrid and GM tree advantages and purposes. Thus, results indicate that if these biotechnologies are deemed appropriate for supporting at-risk species, the majority of land managers in Indiana might be agreeable to such recommendations from researchers. However, it was also clear that despite this, most respondents concurrently had strong ecological concerns about suitability as a native species replacement. To address this, it is essential that these tree types be thoroughly vetted, and land managers be actively engaged in the process, as this population would ultimately be responsible for any widescale implementation of hybrid and GM trees.
\end{abstract}

Keywords Biotechnology · Conservation · Nativeness · Naturalness · Reforestation · Tree management

Andrea N. Brennan

abrennan@mortonarb.org

1 Department of Forestry and Natural Resources, Purdue University, West Lafayette, IN, USA

2 Present Address: The Morton Arboretum, Lisle, IL, USA 


\section{Introduction}

Global changes, such as climate change, habitat loss, and invasive organisms, are impacting tree growth, productivity, and survival (Parker and Gilbert 2004; Niu et al. 2014). Many native tree species are having trouble coping with these changes and are at risk of extinction, an ecological and economic loss (Thomas et al. 2004; Bellard et al. 2016). Some species have increased tolerance to certain stressors resulting from global change (e.g., drought, extreme temperatures, invasive pests and diseases), and incorporation of the genes responsible for this tolerance could be an option in supporting at-risk species. One method of incorporation is through hybridization, the crossing of two different species (Allendorf et al. 2013). Hybridization breeding of native to non-native species is currently being evaluated to aid in restoration of several tree species, such as the American chestnut (Castanea dentata (Marsh.) Borkh.; Clark et al. 2019), butternut (Juglans cinerea L.; Brennan et al. 2020), and American elm (Ulmus americana L.; Pinchot et al. 2017). A second method is genetic modification, or genetic engineering, defined as adding, removing, or changing specific genes through biotechnology (FAO 2010). This approach has been explored less often than hybridization for at-risk tree species restoration, but the American chestnut is a well-known example in which genetic modification has been used to incorporate tolerance to chestnut blight (Jacobs et al. 2013). In addition to incorporation of stress-tolerance genes to support at-risk species, potential advantages of hybridization and genetic modification include accelerating the tree improvement process, improving tree growth and production, and helping solve problems with food supply (Fernandez-Cornejo et al. 1999; Harfouche et al. 2012). However, many concerns, both ecological and economic, have also been associated with the use of both biotechnologies. These include the potential for invasiveness, genetic swamping (when genetic material transfers from one species to another through hybrids and overtime results in one species dominating over the other), high cost, and lack of performance knowledge (Vila et al. 2000; Allendorf et al. 2013; Tsatsakis et al. 2017; NASEM 2019).

As scientists continue to research and evaluate the safety and effectiveness of hybridized and genetically modified (GM) trees, the success of restoration efforts using these trees will be strongly dependent on land manager and public perceptions and acceptance of their use (Hall 2007; Jacobs et al. 2013; Martín et al. 2019). Studies of perceptions towards genetic modification have been primarily focused on agronomic crops and food and were found to be complex, divided, and often negative (Hallman et al. 2003; Costa-Font et al. 2008; Frewer et al. 2013). However, there is limited information on perceptions of GM and particularly hybrid trees, which may differ due to the nature of the plant types and intended use. While some trees are used for food production, trees are more widely used for various other purposes, such as timber production, green infrastructure, wildlife habitat, restoration, and recreation. These could be considered more acceptable uses of hybridization and genetic modification than food production (Merkle et al. 2007; Gamborg and Sandøe 2010). Additionally, with regards to species restoration and conservation, the spread and proliferation of specific pest and disease resistance genes in hybrid or GM trees to wild populations is seen by some stakeholders as a potential goal (Merkle et al. 2007; Strauss et al. 2009). Conversely, given that trees are generally able to spread their pollen and seed further than other types of plants, cultivated hybrid and GM trees in production forest settings may mate and spread into nearby native populations, raising ecological concerns towards the safety of nearby ecosystems (Williams 2005; Hall 2007). Further, trees are much longer-lived than most agronomic food crop plants, which are typically annuals, and 
the long-term ecological implications of hybrid and GM trees could mean greater hesitancy and decreased acceptance to their use (Williams 2005; Hall 2007; Merkle et al. 2007; Gamborg and Sandøe 2010).

So far, research of perceptions towards the use of hybrid and GM trees is limited. Jepson and Arakelyan (2017a) compared perceptions of GM native trees to those of agricultural food crops among informed (knowledgeable) members of the public in the UK. They found that while there was a strong correlation between acceptability of both types, there was stronger approval for GM trees planted in both natural woodland and production forest settings than for GM food crops. However, in a second study by Jepson and Arakelyan (2017b) of the general public, the majority of study participants considered GM trees and food crops equally acceptable or unacceptable. Taken together, these two studies indicate that perceptions to the use of GM trees versus agronomic crops may vary by population.

More specifically for tree-related perceptions, Hajjar et al. (2014) evaluated acceptance of six different forest management strategies in response to climate change by the general public and community leaders in western Canada. In general, the researchers found decreasing acceptance by both the public and community leaders of strategies that involved more manipulation. However, while the strategy of using GM trees had the second lowest level of acceptance, it was still higher than the strategy of no intervention at all. This aligns with the findings of Jepson and Arakelyan (2017a, b), which presented a range of possible solutions to ash dieback in the UK, including the use of GM native ash (Fraxinus L. species) trees with increased disease tolerance. While the use of GM native trees was generally ranked low compared to more conventional planting and breeding strategies, respondents still preferred the use of GM trees over a strategy of no action. Acceptance towards the use of hybrids of native and non-native ash trees was also evaluated in these studies. The hybrid strategy was viewed more favorably than the use of GM trees, but not as highly as conventional breeding and re-planting methods. Perceptions of tree and forest biotechnology have been found to vary by demographic variables, such as age (Jepson and Arakelyan (2017a, b; St-Laurent et al. 2018) and gender (Jepson and Arakelyan 2017a), while the concepts of nativeness and naturalness have also been found to be important in shaping these perceptions (Hajjar and Kozak 2015; Jepson and Arakelyan 2017a). These studies have begun the process of unravelling the complex perceptions towards hybrid and GM tree use, but more remains to be uncovered, especially in direct comparisons of hybrid and GM tree perceptions and the perceived concerns or benefits driving them.

It is also essential to investigate perceptions in specific populations, beyond the 'general public', as this approach may limit the ability to understand the complex motivations of different segments of the population (Fischhoff and Fischhoff 2001). As illustrated previously, there is a small body of literature available on the perceptions of the public and community leaders towards the use of biotechnology (Hajjar et al. 2014; Hajjar and Kozak 2015; Jepson and Arakelyan 2017a, b; St-Laurent et al. 2018); however, information about perceptions of land managers, the people responsible for tree management, is very limited.

While the duties and responsibilities of land managers are typically considered in relation to forestry and management of woodlands or production forests (Jepson and Arakelyan 2017a), here, we consider land managers more broadly to also include those working with trees in urban areas, such as horticulturists, landscape architects, and urban foresters. Land managers not only work on public lands but are often consulted for management of trees on private lands, further extending their impact. As an example, family forest owners, who collectively control $36 \%$ of U.S. forestlands, are not very active in engaging in traditional forestry activities (Butler et al. 2016), but when they do take such management actions, a significant number engage with professionals to help 
plan and execute their actions (Kilgore et al. 2015). Thus, land managers have a strong influence on what trees get planted and where, resulting in a significant impact on both our urban and natural landscapes. This makes it essential to understand not only their perceptions to hybrid and GM trees, but also how those perceptions translate to actual use (here, in the case of hybrid trees only, given current legal restrictions to GM tree use).

The overall goal of this exploratory research was to gauge land manager perceptions to the use of hybrid and GM trees, as well as their current use of hybrid trees. Our research questions were as follows:

1. What are the perceptions of land managers regarding the use of hybrid and GM trees?

2. What factors and characteristics of land managers are associated with their perceptions of hybrid and GM trees?

3. What factors and characteristics of land managers determine their current use of hybrid tree species?

The information generated from this study is meant to aid scientists in engaging with land managers to design research to address potential concerns, and to aid in communicating research results in a way that land managers find relevant in making their tree selection decisions.

\section{Methods}

\section{Study population and recruitment}

For the purposes of this study, land managers were defined as professionals and/or volunteers involved with tree selection, sale/distribution, management, and/or planting of trees in Indiana, USA. Indiana was chosen as it is well-situated within the Central Hardwoods Region and is within the native range of several tree species in which hybrid and/or GM trees are actively being developed or considered, such as American chestnut (Jacobs et al. 2013), butternut (Brennan et al. 2020; Pike et al. 2020), and American elm (Pinchot et al. 2017). There was no comprehensive sampling frame of land managers in Indiana available. As discussed previously, land managers are a wide and diverse group involved with multiple land and organization types, and are not accessible by any single, or even a few, venues. This makes developing a comprehensive sampling frame challenging. In order to reach as many land managers operating in Indiana as possible, participants were recruited through different professional and governmental organizations and groups. Specifically, the researchers assembled a list of publicly available email addresses for forestry and natural resource professionals in Indiana, including district foresters, consulting foresters, land trust employees, and other professionals from state government, federal government, and non-profit land management organizations. The membership of many large organizations and professional societies were not publicly available online, but still constitute an important portion of land managers in Indiana. In order to reach these individuals, the leadership of these organizations distributed our survey to their membership on our behalf or gave us permission and access to contact them directly. For a complete list of the 46 organizations and professional groups reached by the survey invitation see Appendix S1. 


\section{Data sources}

Data for this study was collected through an online survey informed by preliminary, semistructured interviews with nine land managers with extensive knowledge of the land manager population in Indiana. Prior to implementation, the interview and survey recruiting emails, interview protocol, and survey questionnaire were approved by Purdue University's Institutional Review Board (Protocol No. 1805020620). The online survey was created and distributed following the Tailored Design Method (Dillman et al. 2014). All participants able to be recruited directly received an initial email invitation and three waves of reminders. Survey invitations distributed through organizational leadership took the form of an email invitation, article in the organization's e-newsletter, and/or post on the organization's Facebook page. Individuals contacted this way received either one or no reminders, at the discretion of organization leadership. The survey was composed of 26 multiple-choice and Likert-scale questions divided into five sections: (1) work/volunteer background, (2) hybrid plants, (3) GM plants, (4) at-risk plants, and (5) demographic characteristics. Within the hybrid and GM sections, respondents were asked about their perceived tree improvement advantages and concerns to using these tree types and their level of agreement on using them for different purposes. The concerns were divided into economic and ecological types. We acknowledge that these two concern concepts could be interconnected; however, we presented them in the survey in a separate manner because that was how the land managers in the preliminary qualitative work of this study discussed these concerns. In the hybrid section respondents were also asked to indicate whether they currently use hybrid trees in their job or volunteer work. Since some of the issues covered in the survey may be less familiar to some land managers, definitions were provided at the beginning of the survey and again as needed throughout the survey as in Table 1. The complete survey protocol is in Appendix S2.

The survey was live February through April 2019. After removing responses from those who did not mark themselves as Indiana land managers or that did not complete any of the perceptions or use questions, we ultimately received 273 usable survey responses. We attempted to reach every land manager in the state as described above, and additionally, the leadership of several organizations disseminated the survey invitation to their membership on our behalf. In these cases, it was not possible to control the precise timing of when certain groups received the survey invitation and/or reminders. As such, we could not conduct a nonresponse bias check by comparing early responses to later responses (Groves 2006;

Table 1 Definitions of concepts used in the survey

\begin{tabular}{ll}
\hline Concept & Definition \\
\hline $\begin{array}{l}\text { Hybrid } \\
\text { Genetic modification }\end{array}$ & $\begin{array}{c}\text { Offspring resulting from the cross of two different species (Allendorf et al. 2013) } \\
\text { Adding, removing, or changing specific genes through biotechnology (Walter and } \\
\text { Menzies 2010) } \\
\text { At-risk species }\end{array}$ \\
$\begin{array}{l}\text { A species at risk of being lost from the landscape, due to threats such as exotic pests } \\
\text { or pathogens, climate change, and habitat loss (USGS 2020) }\end{array}$ \\
$\begin{array}{l}\text { Excessive introgression; when genetic material transfers from one species to another } \\
\text { over time through hybrids and results in one species dominating over the other (ex: } \\
\text { Chinese bittersweet over American bittersweet growing in the US) (Todesco et al. } \\
\text { 2016) } \\
\text { Non-native species }\end{array}$ \\
\begin{tabular}{l} 
Not native to the region prior to European settlement (NRCS 2020) \\
\hline
\end{tabular}
\end{tabular}


Groves and Peytcheva 2008). Instead, we evaluated the responses for each land manager subgroup (by characteristic) to ensure that different types of land managers were well represented. We also consulted experts in the field to assure that the demographics seen in the survey matched with their perceived composition of the land manager population in Indiana.

\section{Data analysis}

Statistical analysis was conducted using R version 3.6.2 (R Core Team 2019). Very little is known about the land manager population in Indiana, so this study was primarily exploratory and descriptive in nature, designed to establish a foundational understanding of land managers' hybrid- and GM-related perceptions and management practices and intention, providing a basis for generating hypotheses for further quantitative investigations and for identifying gaps and tensions for future in-depth qualitative inquiries (Knupfer and McLellan 1996; Grimes and Schulz 2002). As such, univariate descriptive statistics were used for quantifying perceptions (first research question). To assist with interpretation for the second and third research questions, dimensionality of variables related to ecological and economic concerns, tree improvement advantages, and purpose of use were reduced using a summated scale (Spector 1992), creating new composite variables (Table 2). Advantage and concern sub-variables were summated according to how they were grouped and presented in the survey protocol. The composite variables created for potential purposes of use were grouped by creating a new restoration purpose variable and four others (provisioning, supporting, regulating, and cultural purposes) using the Ecosystems Services Framework as a guide (Millennium Ecosystem Assessment 2005). Correlations and Cronbach's Alpha (Cronbach 1951) were used to verify the internal consistency of each grouping. The new composite economic concern variable for both tree types came close, but did not meet the suggested minimum of 0.7 for Cronbach's Alpha (Nunnally 1978), so caution is needed in interpretation involving these variables. While in the survey protocol (Appendix S2) respondents were given six different possible levels of education, for the final statistical analysis, the levels were collapsed into high school degree or equivalent/ some college/ Associate's degree, Bachelor's degree, and graduate degree in order to attain an adequate sample size in each category.

Responses regarding concern levels, hybrid type preference, whether a GM tree is native, and the concern comparison for hybrid versus GM trees were analyzed using Pearson's Chi-Square Test in base $\mathrm{R}$ to address the second research question about characteristics of land managers associated with perceptions. When any assumptions of Pearson's Chi-Square Test were violated, Fisher's Exact Test was conducted instead. To further address the second research question, perceptions of tree improvement advantages and purposes of use were analyzed using cumulative link models (also called ordinal regression or proportional odds models) with R package 'ordinal' (Christensen 2019), in conjunction with 'car' (Fox and Weisberg 2019), and 'RVAideMemoire' (Hervé 2020) to determine the likelihood ratio chi-square and $p$-value of variable effects. The analysis of land manager characteristics associated with current use of hybrid tree species was conducted by calculating average marginal effects in logistic regression using $\mathrm{R}$ package ' $\mathrm{mfx}$ ', which allows for the use of ordinal explanatory variables (Fernihough and Henningsen 2019). We did not include the primary purpose of work land manager characteristic in the final statistical models because a small number of responses in some of the response categories made it not statistically valid to do so. 
Table 2 Description of new, composite variables of level of concern or dis-/agreement regarding perceptions associated with hybrid and GM trees created to reduce dimensionality using a summated scale. The original variables averaged to create the composite variables are indented below each new variable

\begin{tabular}{ll}
\hline Variable & Cronbach's Alpha \\
\cline { 2 - 2 } & Hybrid trees GM trees
\end{tabular}

Strongly disagree to strongly agree

Tree improvement advantages

-Accelerating the tree improvement process

-Improved tree growth and production

-Better resource-use efficiency

-Greater site suitability and functionality

-Greater stress and pest resistance

-Decreased need for pesticide applications

-Helping solve problems with the food supply

Restoration purposes

-Reforestation and restoration of forests

-Conservation and restoration of at-risk species (plant or animal)

Supporting purposes

-Promoting wildlife/habitat creation

-Promoting biodiversity

Provisioning purposes

-Timber production

-Non-timber production (fruit, nuts, syrup, etc.)

Regulating purposes

-Regulating ecosystem services (storm water management, erosion control, carbon storage, clean air, etc.)

-Green infrastructure and managed landscapes

Cultural purposes

-Aesthetic value

-Recreation

Not concerned to very concerned

Ecological concerns

-Changes induced in local ecosystem

-Genetic swamping of native population

-Potential for invasiveness

-Negative effects on wildlife

Economic concerns

-Low availability

-Expensive to buy and produce

-Lack of performance knowledge

\section{Results}

\section{Profile of respondents}

Land manager respondents ranged from 23-78 years in age, with a mean of 47 years old. 
Seventy-nine percent of respondents identified themselves as male and $86 \%$ of all respondents reported having a bachelor's or graduate degree. There was no evidence that education differed by gender $\left(\chi^{2}=3.334 ; p=0.189\right)$. Respondents' county of residence was nearly evenly split between northern (49\%) and southern counties (51\%) of Indiana. Respondents had spent an average of 14 years in their current organization, with a range of $1-47$ years. Sixty-one percent of respondents managed natural lands for their tree management work. The predominant client types identified by survey respondents were general public $(65 \%)$ and private landowners (60\%). The most common primary work purposes (ranked as number one) were timber production (18\%), promoting wildlife habitat/creation (17\%), and restoration and reforestation (15\%). Extended demographic information of respondents is included in Appendix S3: Tables S1 and S2.

\section{Overall concerns about hybrid vs. GM trees}

We asked land managers how they think about using hybrid versus GM trees in a hypothetical sense (see Appendix S2 for survey protocol). The majority of survey respondents reported having similar levels of concerns with the use of both hybrid and GM trees (43\%). Thirty-five percent reported having more concerns about GM than hybrid trees, while $11 \%$ reported having more concerns about hybrid than GM trees. Ten percent of respondents reported "don't know". Of all the land manager characteristics, age and education were the only two variables statistically significantly associated with respondents' relative concern of hybrid versus GM trees. Specifically, younger respondents (23-40 years old) reported having more concerns about hybrid trees, while those in the older age groups (41-59 and $60-78$ years old) reported having more concerns about GM trees $\left(\chi^{2}=13.92 ; p=0.030\right)$. Those with more education (bachelor's or graduate degree) were more likely to report having similar levels of concerns with the use of both hybrid and GM trees, while those with less education (high school degree, some college, or an associate's degree) were more likely to report having more concerns about one than the other $\left(\chi^{2}=14.025 ; p=0.029\right)$. All other variable relationships were non-significant. For the full statistics of association of land manager characteristics with this concern comparison see Appendix S3: Table S3.

\section{Hybrid tree perceptions and current use}

\section{Perceived hybrid tree improvement advantages}

Generally, there was more agreement than disagreement regarding the tree improvement advantages of hybrid trees (Fig. 1a). Respondents had the greatest agreement (agree or strongly agree) with using hybrid trees for "greater stress and pest resistance" (70\%) and "improved tree growth and production" (62\%). In contrast, respondents had the least agreement (strongly disagree or disagree) with using hybrid trees for "greater site suitability and functionality" (19\%) and "better resource-use efficiency" (19\%). It should be noted, however, that disagreement was similarly low across all advantage variables. Those working in for-profit organizations were more likely to agree with tree improvement advantages of hybrid trees than those in state government $\left(\chi^{2}=14.706 ; p=0.012\right)$, but age, gender, education, region of residency in Indiana, and land type managed were not associated with agreement regarding tree improvement advantages of hybrid trees (see Table 3 for full statistical values). 


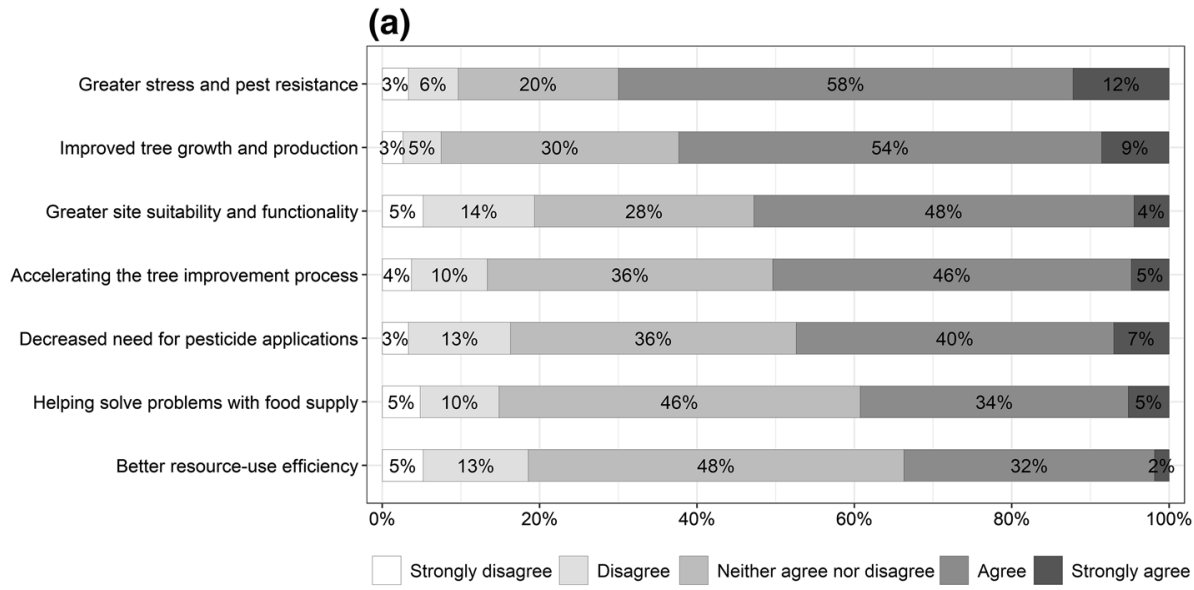

(b)

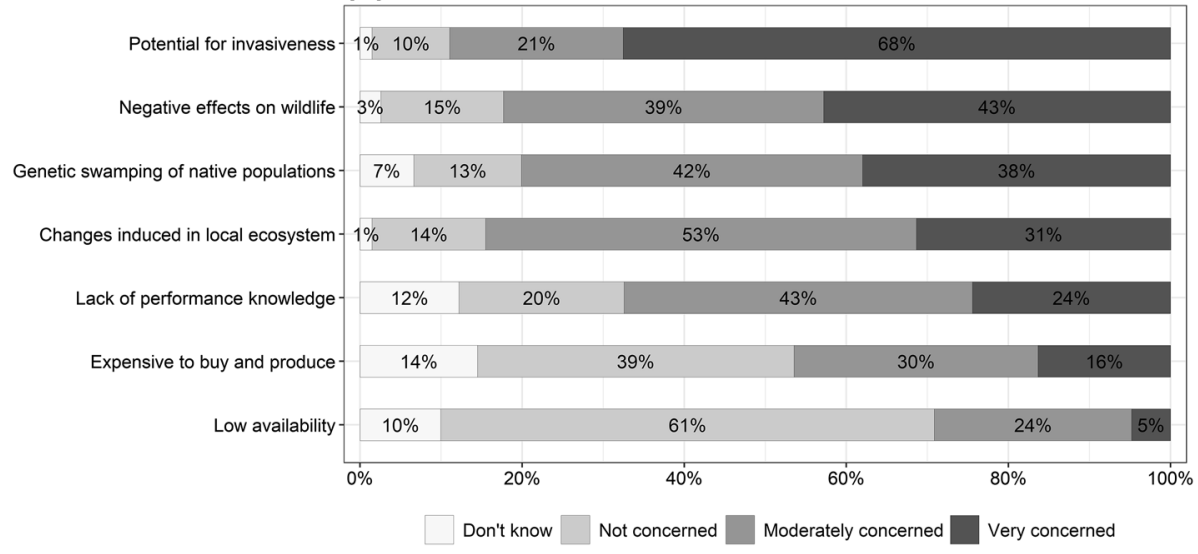

Fig. 1 Survey respondents' perceived a tree improvement advantages of hybrid trees, in order of decreasing agreement, and $\mathbf{b}$ concerns, in order of decreasing concern $(n=271)$

\section{Concerns about hybrid trees}

Ecological concerns about hybrid trees (potential for invasiveness, negative effects on wildlife, genetic swamping, and ecosystem changes) were consistently stronger than economic concerns (performance, expense, and availability) (Fig. 1b). The greatest ecological concern about hybrid trees was the potential for invasiveness (68\% strongly concerned), while negative effects on wildlife was the least important ecological concern (15\% not concerned). In contrast, the greatest economic concern was the lack of performance knowledge ( $24 \%$ strongly concerned), while low availability was the least important economic concern (61\% not concerned).

Of the various land manager characteristics and perceptions (see Table 2 for the list of variables), level of agreement with hybrid tree improvement advantages was the only variable significantly associated both with ecological and economic concerns, but the direction of the relationship depended on the type of concern (Table 3). A higher level of ecological concerns was associated with less agreement with hybrid trees having tree improvement 


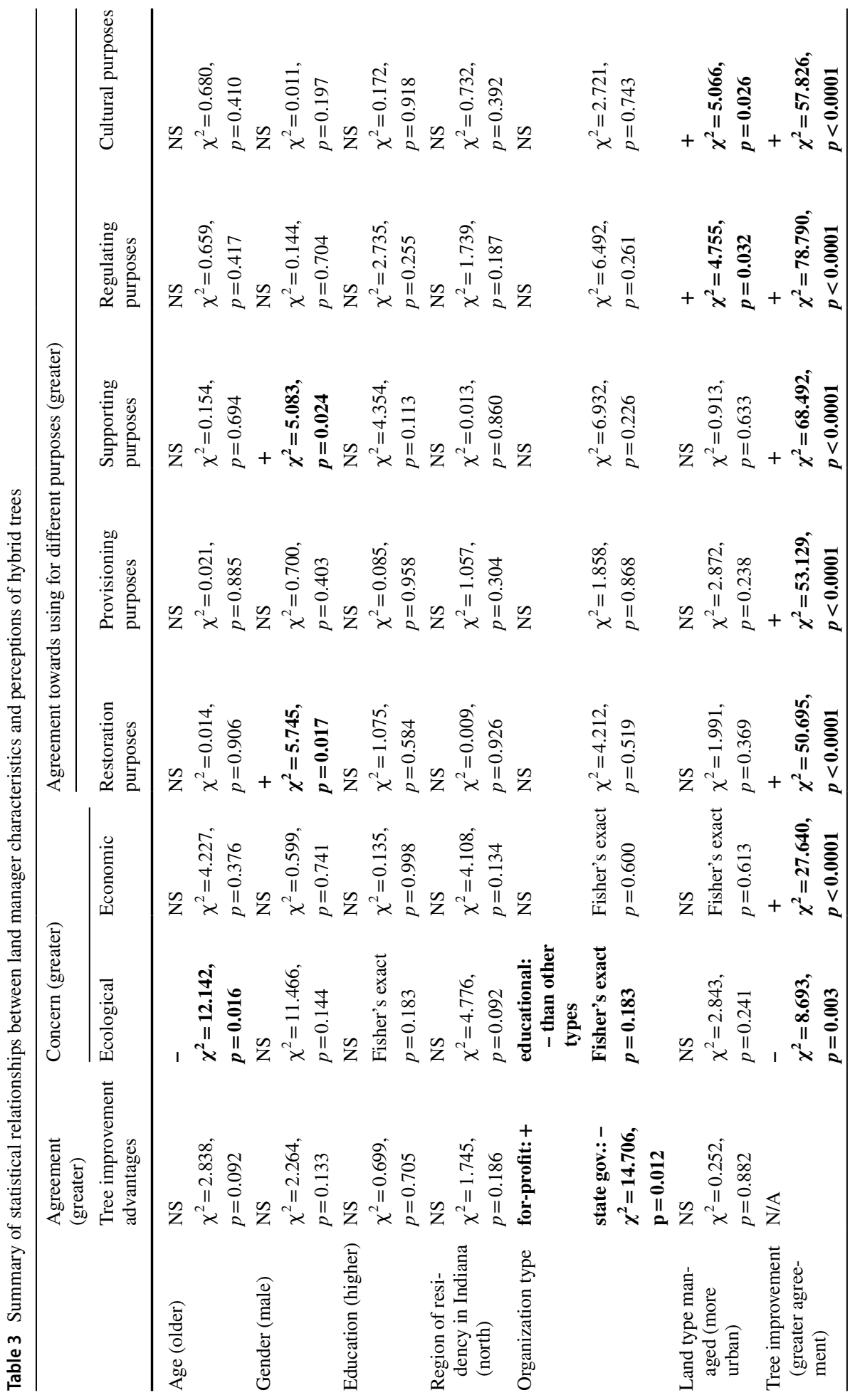




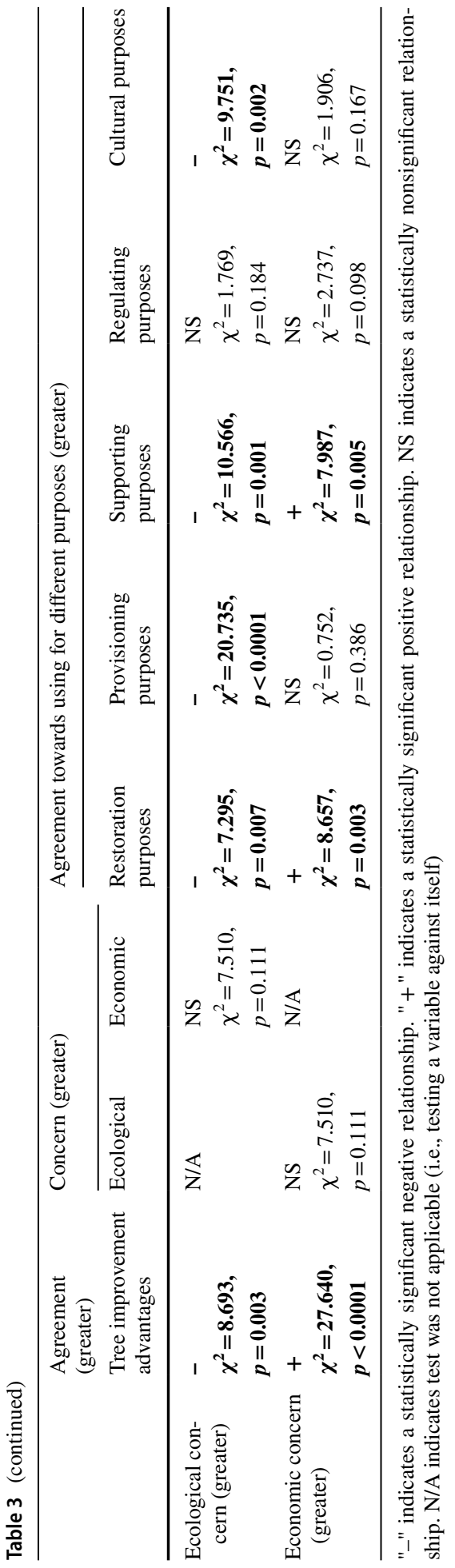


advantages $\left(\chi^{2}=8.693 ; p=0.003\right)$. Conversely, a higher level of economic concerns was associated with greater agreement with hybrid trees having tree improvement advantages $\left(\chi^{2}=27.640 ; p<0.0001\right)$. There was also a significant negative association between ecological concerns about hybrid trees and age, with decreasing concern with increasing age $\left(\chi^{2}=12.142 ; p=0.016\right)$. Ecological concern about hybrid trees was also associated with organization type, with those working in university and educational organizations having less concern than those in other organization types (Fisher's exact $p=0.011$ ). The level of ecological concerns was not associated with the level of economic concerns about hybrid trees among our respondents. Further, gender, education, region of residency in Indiana, and land type managed were not associated with either ecological or economic concerns about hybrid trees (see Table 3 for statistical values of non-significant relationships).

\section{Attitudes towards using hybrid trees for different purposes}

Overall, there was more agreement than disagreement regarding the use of hybrid trees for various purposes (Fig. 2). The top three purposes for using hybrid trees with the greatest agreement (agree or strongly agree) among land managers were "non-timber production" (63\%), "timber production" (59\%), and "conservation and restoration of at-risk species" (57\%). The purposes for using hybrid trees with the greatest disagreement (strongly disagree or disagree) were "promoting biodiversity" (32\%), "reforestation and restoration of forests" (30\%), and "promoting wildlife habitat" (27\%).

Two land manager characteristics were associated with their attitudes towards using hybrid trees for different purposes. Specifically, if a land manager managed urban land, they were more likely to agree with using hybrid trees for the purpose of generating regulating $\left(\chi^{2}=4.755 ; p=0.032\right)$ and cultural ecosystem services $\left(\chi^{2}=5.066 ; p=0.026\right)$. Self-identifying as a male was also associated with greater agreement with using hybrid trees for restoration $\left(\chi^{2}=5.745 ; p=0.017\right)$ and generating supporting ecosystem services

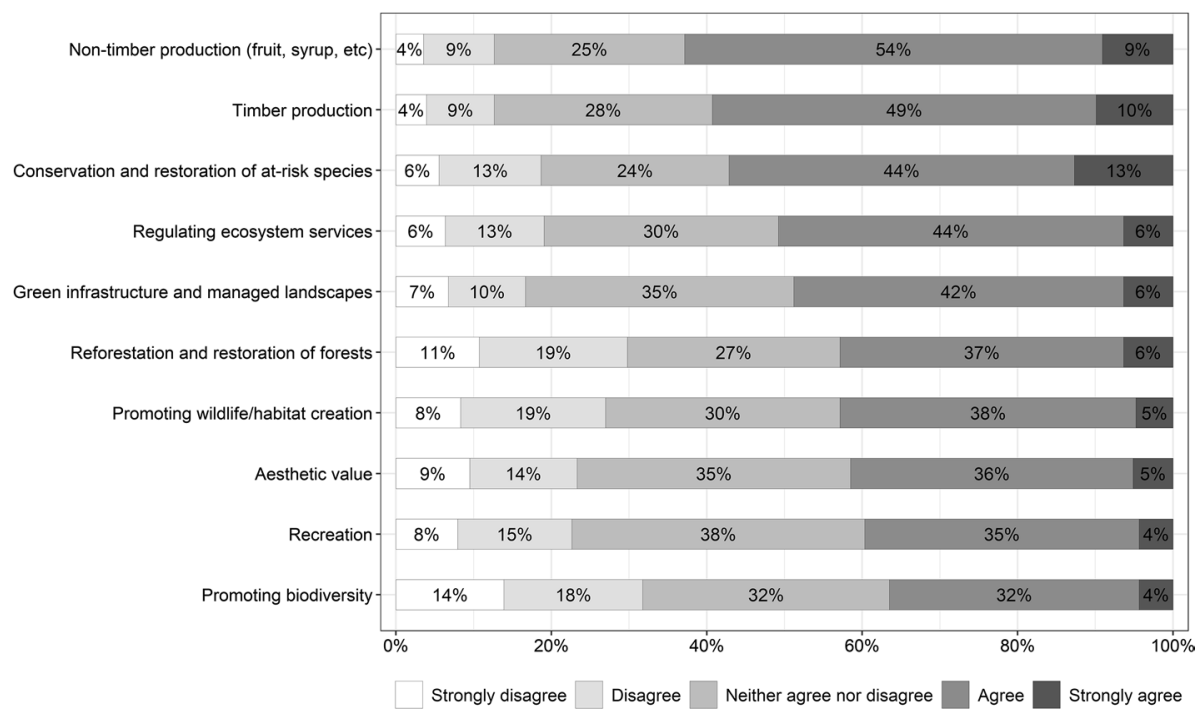

Fig. 2 Survey respondents' attitudes towards using hybrid trees for various purposes, in order of decreasing agreement $(n=253)$ 
$\left(\chi^{2}=5.083 ; p=0.024\right)$. Age, education, region of residency in Indiana, and organization type were not associated with agreement regarding the use of hybrid trees for various purposes (see Table 3 for statistical values). In addition to these bivariate relationships, there was a strong positive relationship between land managers perceiving tree improvement advantages of hybrid trees and their agreement with using hybrid trees for all five purposes: restoration $\left(\chi^{2}=50.695 ; p<0.0001\right)$, provisioning ecosystem services $\left(\chi^{2}=53.129\right.$; $p<0.0001)$, supporting ecosystem services $\left(\chi^{2}=68.492 ; p<0.0001\right)$, regulating ecosystem services $\left(\chi^{2}=78.790 ; p<0.0001\right)$, and cultural ecosystem services $\left(\chi^{2}=57.826\right.$; $p<0.0001$ ) (Table 3). Land managers' level of economic concerns was also positively associated with agreement with using hybrid trees for restoration $\left(\chi^{2}=8.657 ; p=0.003\right)$ and supporting ecosystem services purposes $\left(\chi^{2}=7.987 ; p<0.0001\right)$. However, the level of ecological concerns was negatively associated with agreement with using hybrid trees for restoration $\left(\chi^{2}=7.295 ; p=0.007\right)$, provisioning ecosystem services $\left(\chi^{2}=20.735\right.$; $p<0.0001)$, supporting ecosystem services $\left(\chi^{2}=10.566 ; p=0.001\right)$, and cultural ecosystem services $\left(\chi^{2}=9.751 ; p=0.002\right)$, but not for regulating ecosystem services $\left(\chi^{2}=2.737\right.$; $p=0.098)$.

\section{Hybrid type preference for restoration}

We presented respondents with two hybrid types for use in restoration. Seventy-four percent of respondents preferred the native species $\times$ native species hybrid type for use in restoration, while none of the respondents preferred the native species $\times$ non-native species hybrid type. Nine percent of respondents preferred either type, while $13 \%$ preferred neither type. Four percent of respondents selected "don't know". There was a significant association between hybrid type preference and age, with respondents in the older age bracket (60-78 years old) indicating stronger preferences for both hybrid types than those in the younger age brackets (23-40 and 41-59 years old; Fisher's exact $p=0.026$ ). Gender was also associated with preference, with more female respondents than male respondents preferring neither hybrid type (Fisher's exact $p=0.006$ ). Additionally, the more ecologically concerned respondents were about hybrid trees, the more likely they preferred neither hybrid type; relatedly, the less ecologically concerned respondents were about hybrid trees, the more likely they preferred either hybrid type (Fisher's exact $p=0.002$ ). Those who were less agreeable with the tree improvement advantages of hybrid trees were also less likely to prefer either hybrid type (Fisher's exact $p<0.0001$ ). No other land manager characteristics were associated with hybrid type preference; for the full statistics see Appendix S3: Table S4.

\section{Current use of hybrid trees}

Twenty-nine percent of land managers reported using hybrid trees in their work, while $62 \%$ reported not using them, and $9 \%$ did not know whether they were using hybrid trees or not. A list of the specific hybrid species respondents reported using in their work is included in Appendix S3: Table S5. The percent of land managers self-reporting hybrid tree use is presented by characteristic in Table 4. Land managers in local government or non-profit organizations were more likely to use hybrid trees than those in state government $(p=0.040$ and 0.035 , respectively; Table 5). The type of land managed was also significantly associated with whether hybrid trees were used; those managing urban lands were more likely to use hybrid trees $(p=0.001)$. Those with higher levels of ecological concerns were less likely 


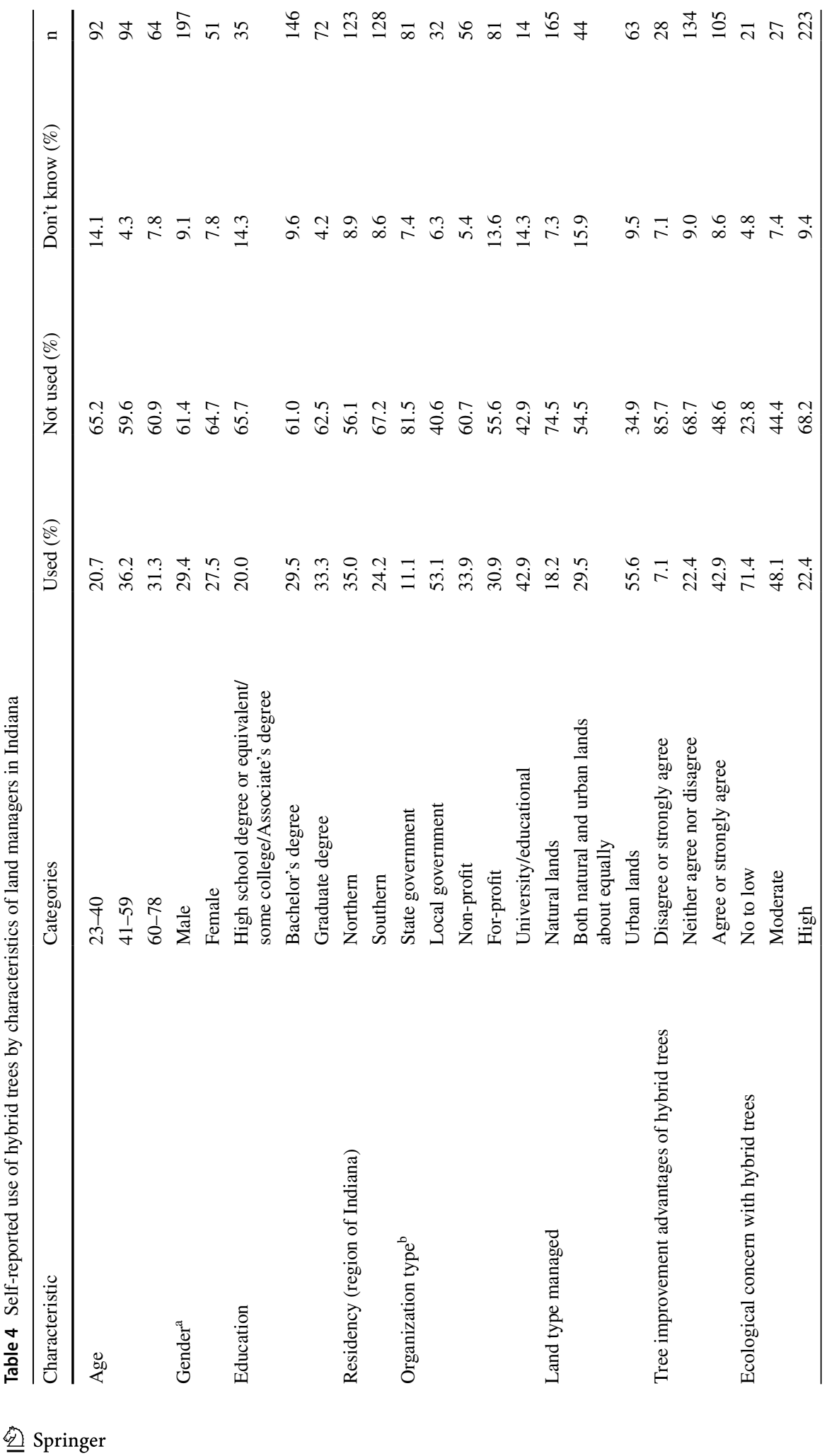




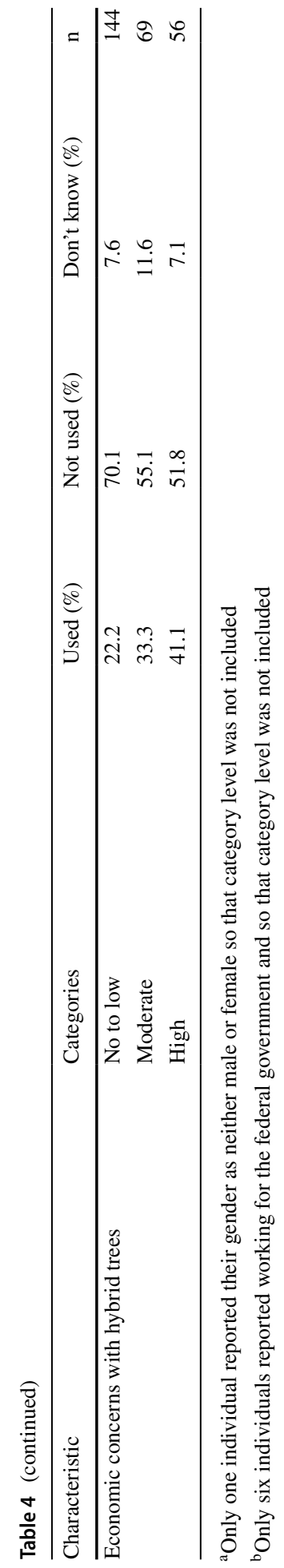


Table 5 Logistic estimates of the empirical models for estimating use of hybrid trees by land managers in Indiana $(\mathrm{n}=230)$.

\begin{tabular}{lccc}
\hline Explanatory variables & AME & SE & $p$-value \\
\hline Age (greater) & 0.001 & 0.002 & 0.780 \\
Gender: female & -0.039 & 0.059 & 0.511 \\
Education (greater) & 0.115 & 0.064 & 0.070 \\
Region of Indiana: south & -0.002 & 0.051 & 0.970 \\
Organization: local government & $\mathbf{0 . 2 1 8}$ & $\mathbf{0 . 1 0 6}$ & $\mathbf{0 . 0 4 0}$ \\
Organization: for-profit & 0.101 & 0.074 & 0.175 \\
Organization: non-profit & $\mathbf{0 . 1 6 2}$ & $\mathbf{0 . 0 7 7}$ & $\mathbf{0 . 0 3 5}$ \\
Organization: university/educational & 0.113 & 0.154 & 0.463 \\
Land type managed (more urban) & $\mathbf{0 . 1 8 3}$ & $\mathbf{0 . 0 5 6}$ & $\mathbf{0 . 0 0 1}$ \\
Agreement of tree improvement advantages of hybrid trees & 0.204 & 0.106 & 0.055 \\
$\quad$ greater) & & & \\
Ecological concern with hybrid trees (greater) & $\mathbf{- 0 . 4 8 4}$ & $\mathbf{0 . 1 3 3}$ & $\mathbf{0 . 0 0 0 3}$ \\
Economic concern with hybrid trees (greater) & 0.140 & 0.075 & 0.064 \\
\hline
\end{tabular}

Data reported for all ordinal variables represents the linear relationship between levels. None of the higher order relationships (ex: quadratic) tested significant and were excluded to conserve space

Average marginal effects (AME) were used with standard error (SE). The reference level for organization type was state government

to use hybrid trees $(p=0.001)$, while the level of economic concern was not significantly associated with hybrid tree use. There was also no relationship between hybrid tree use and age, gender, education, region of Indiana, or agreement with tree improvement advantages of hybrid trees (see Table 5 for the full statistics).

\section{GM tree perceptions}

\section{Perceived GM tree improvement advantages}

Overall, there was more agreement than disagreement regarding the tree improvement advantages of GM trees (Fig. 3a). Respondents had the greatest agreement (agree or strongly agree) with using GM trees for the purposes of "greater stress and pest resistance" (68\%) and "improved tree growth and production" (61\%). In contrast, respondents had the least agreement (strongly disagree or disagree) with using GM trees for "greater site suitability and functionality" (19\%) and "herbicide tolerance" (19\%). It should be noted that disagreement was fairly consistent across the tree improvement advantages. While gender, education, region of residency in Indiana, and land type managed were not associated with agreement regarding tree improvement advantages of GM trees (see Table 6 for full statistical values), age was negatively associated with agreement with GM trees having tree improvement advantages $\left(\chi^{2}=4.602 ; p=0.032\right)$.

\section{Concerns about GM trees}

Trends in level and type of concerns about GM trees closely followed those about hybrid trees. Ecological concerns about GM trees were consistently stronger than economic 


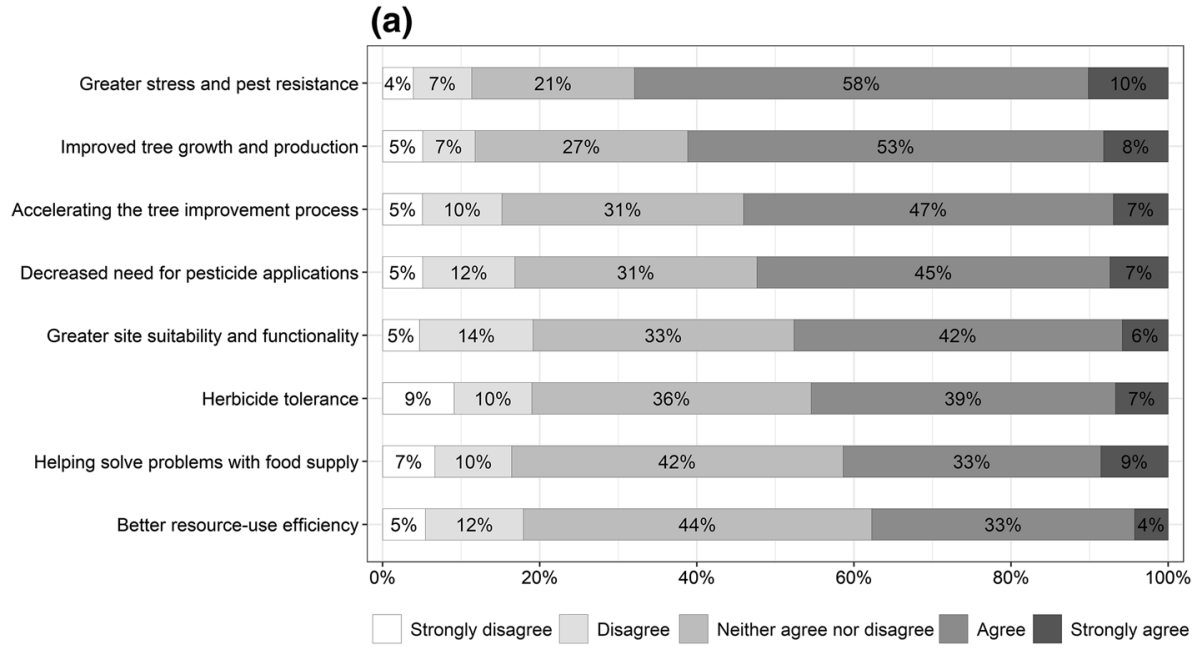

(b)

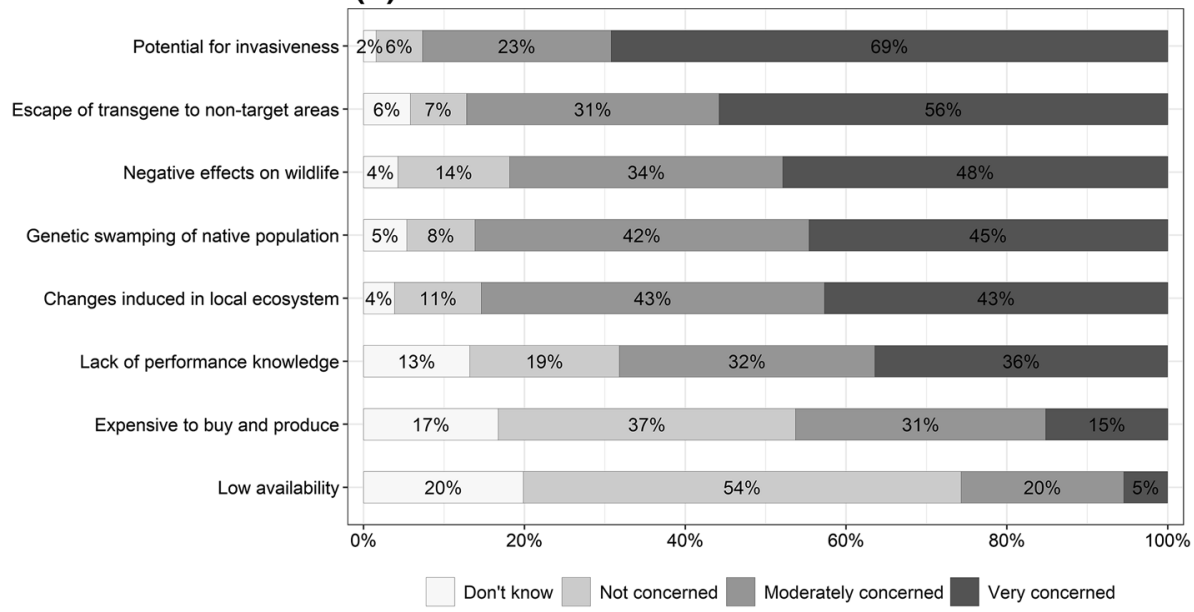

Fig. 3 Survey respondents perceived a tree improvement advantages of GM trees, in order of decreasing agreement, and $\mathbf{b}$ concerns, in order of decreasing concern $(n=260)$

concerns (Fig. 3b). The greatest concern about GM trees overall was the potential for invasiveness (69\% strongly concerned). The greatest economic concern about GM trees was the lack of performance knowledge (36\% strongly concerned). Low availability was the least important economic concern (54\% not concerned).

As with hybrid trees, the only land manager characteristic and perception variable significantly associated with both ecological and economic concerns about GM trees was the level of agreement with tree improvement advantages, with the direction of the relationship depending on the type of concern (Table 6). A higher level of ecological concerns about GM trees was associated with less agreement with GM trees having tree improvement advantages $\left(\chi^{2}=5.454 ; p=0.020\right)$. Conversely, a higher level of economic concerns was associated with greater agreement with GM trees having tree improvement advantages $\left(\chi^{2}=20.415 ; p<0.0001\right)$. The level of economic concerns about GM trees was positively 


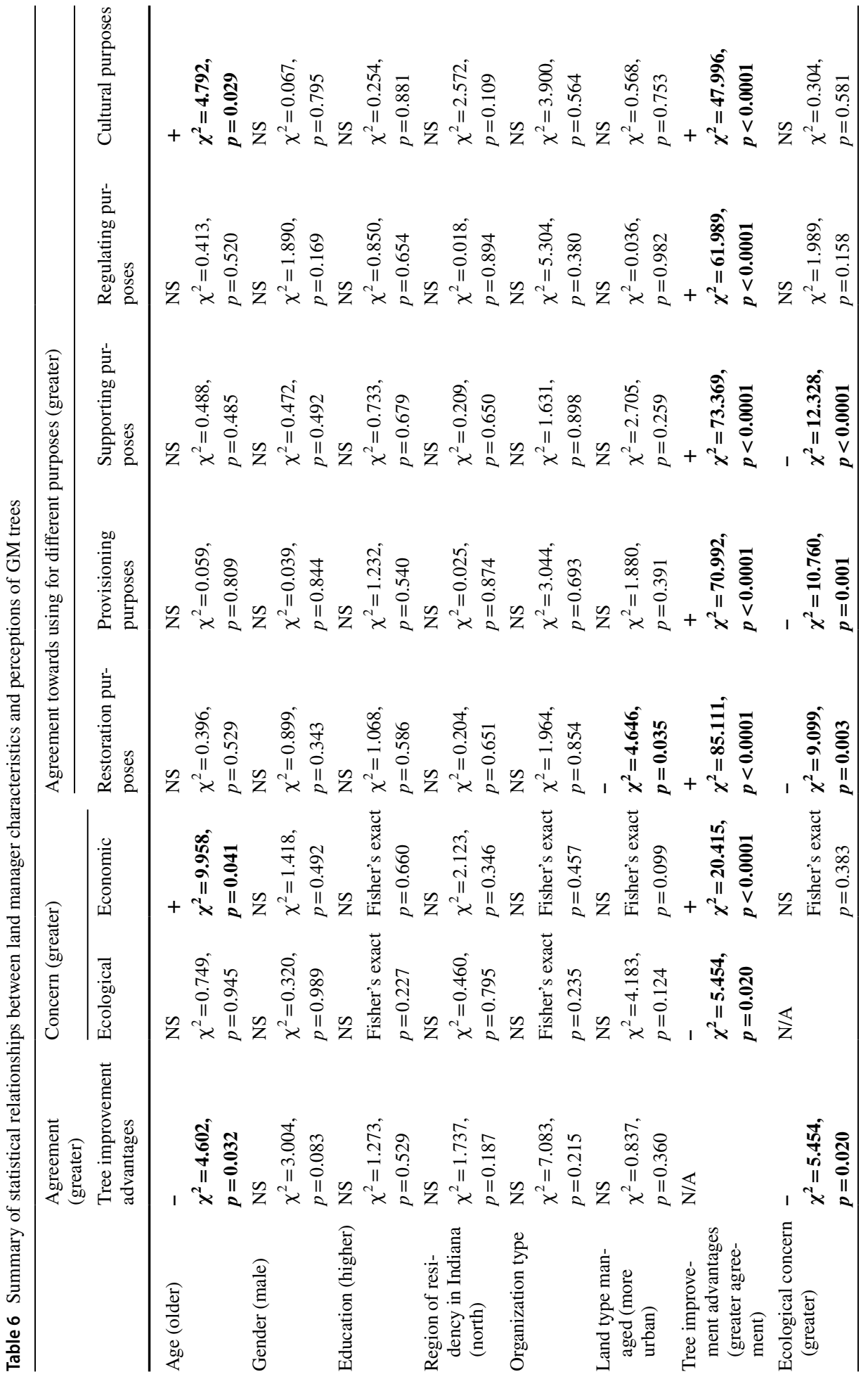




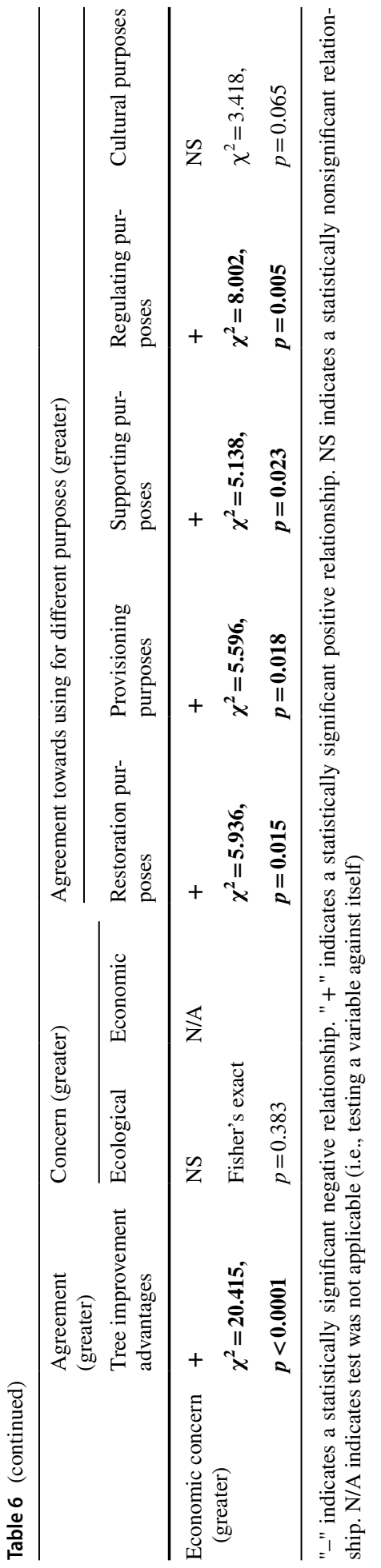


associated with age, with concern increasing with age $\left(\chi^{2}=9.958 ; p=0.041\right)$. The level of ecological concerns was not associated with the level of economic concerns about GM trees (see Table 6), nor any land manager characteristics (i.e., gender, education, region, organization type, land type managed) (see Table 6 for all statistical values of non-significant relationships).

\section{Attitudes towards using GM trees for different purposes}

Overall, there was more agreement than disagreement for using GM trees for various proposes (Fig. 4). There was greatest agreement (agree or strongly agree) among land managers with using GM trees for "conservation and restoration of at-risk species" (56\%), "timber production" (54\%), and "non-timber production" (47\%). The purposes for using GM trees with the greatest disagreement (strongly disagree or disagree) were "promoting biodiversity" (39\%), "reforestation and restoration of forests" (34\%), and "promoting wildlife habitat" (33\%).

As with hybrid trees, two land manager characteristics were associated with attitudes towards using GM trees for different purposes. Respondents managing urban land were less likely to agree with using GM trees for restoration purposes $\left(\chi^{2}=4.646 ; p=0.035\right)$, but type of land managed was not associated with agreement for other purposes (see Table 6). Age was only associated with agreement with using GM trees for cultural ecosystem services, with agreement increasing with age $\left(\chi^{2}=4.792 ; p=0.029\right)$. Neither gender, education, region of residency in Indiana, nor organization type was associated with agreement for using GM trees for any purposes (see Table 6). In addition, agreement with the tree improvement advantages of GM trees was strongly and positively associated with agreement with using GM trees for all five purposes: restoration $\left(\chi^{2}=85.111 ; p<0.0001\right)$, provisioning ecosystem services $\left(\chi^{2}=70.992 ; p<0.0001\right)$, supporting ecosystem services $\left(\chi^{2}=73.369 ; p<0.0001\right)$, regulating ecosystem services $\left(\chi^{2}=61.989 ; p<0.0001\right)$, and

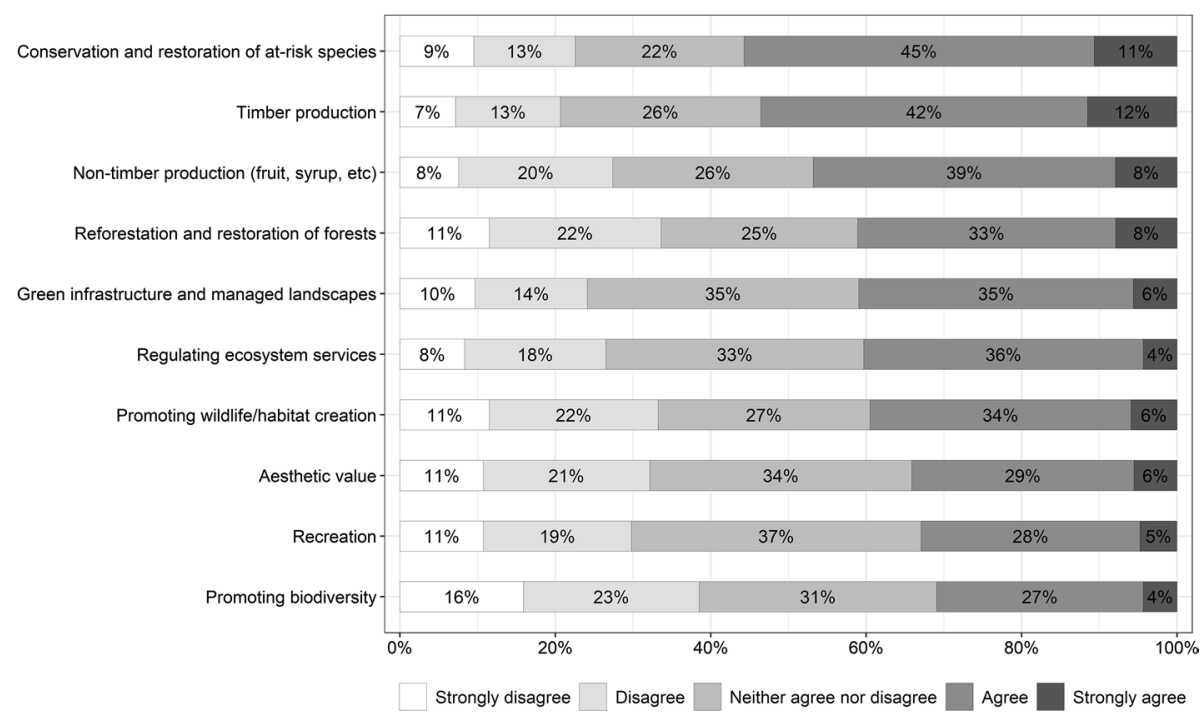

Fig. 4 Survey respondents' attitudes towards using GM trees for various purposes, in order of decreasing agreement $(n=253)$ 
cultural ecosystem services $\left(\chi^{2}=47.996 ; p<0.0001\right)$ (Table 6$)$. There was also a positive relationship between land managers' level of economic concerns and their agreement with using GM trees for restoration $\left(\chi^{2}=5.936\right.$; $\left.p=0.015\right)$, provisioning ecosystem services $\left(\chi^{2}=5.596 ; p=0.018\right)$, supporting ecosystem services $\left(\chi^{2}=5.138 ; p=0.023\right)$, and regulating ecosystem services $\left(\chi^{2}=8.002 ; p=0.005\right)$, but not for cultural ecosystem services $\left(\chi^{2}=3.418 ; p=0.065\right)$. Conversely, level of ecological concern was negatively associated with agreement with using GM trees for restoration $\left(\chi^{2}=9.099 ; p=0.003\right)$, provisioning ecosystem services $\left(\chi^{2}=10.760 ; p=0.001\right)$, and supporting ecosystem services $\left(\chi^{2}=12.328 ; p<0.0001\right)$, but not for regulating ecosystem services $\left(\chi^{2}=1.989 ; p=0.158\right)$ and cultural ecosystem services $\left(\chi^{2}=0.304 ; p=0.581\right)$.

\section{Perceived nativity of GM trees}

Forty-seven percent of respondents perceived a GM version of a native species as not being native, while $26 \%$ said that it would still be native and $27 \%$ reported "don't know". Respondents with higher levels of ecological concerns about GM trees were more likely to perceive a GM version of a native species as not native, while those with lower levels of ecological concerns were more likely to perceive it as native (Fisher's exact $p<0.0001$ ). Further, respondents with stronger agreement with the tree improvement advantages of GM trees were more likely to perceive a GM version of a native species as still being native $\left(\chi^{2}=38.488 ; p<0.0001\right)$. No other land manager characteristics or perceptions were associated with perceived nativity of GM trees (for the full statistical values see Appendix S3: Table S6).

\section{Discussion}

\section{Perceived concerns and risks about hybrid and GM trees}

Our results indicate that land mangers tend to be more concerned about the ecological rather than economic impacts of both tree types, despite that the impacts of hybrid trees have been more extensively assessed than that of the much newer GM trees, which may be legally grown under only limited situations (Sedjo 2010). Hybrid trees have been actively used and planted for centuries, in addition to naturally forming from introduced nonnative species crossing with native species. As such, their ecological impacts have been documented across a range of landscapes (Burgess and Husband 2006; Zalapa et al. 2009; Gaskin 2016; Cronk and Suarez-Gonzalez 2018). Yet, our results suggest similar levels and types of concerns about hybrid (Fig. 1b) and GM trees (Fig. 3b).

To understand these results, we look at the case of American chestnut hybrids. Backcross breeding species conservation efforts have been made to preserve as many of the traits from the native progenitor as possible to enable them to serve as an adequate substitute for the unhybridized species, and with some success (Diskin et al. 2006; Knapp et al. 2014). However, American chestnut hybrid breeding programs are still in-progress and long-term effects are yet unknown. Ecological issues associated with other hybrid trees with a non-native progenitor, including invasiveness and genetic swamping, have also been documented, such as with white mulberry (Morus alba L.; Burgess and Husband 2006), Callery pear (Pyrus calleryana Decne.; Culley and Hardiman 2007), and Siberian elm (Ulmus pumila L.; Zalapa et al. 2009). Together, these studies have painted an ecologically 
checkered history of hybrids, potentially shaping land managers' perceptions of hybrid trees. Social science research has also shown that humans have stronger experiential, rather than analytical, processing systems and that personal experiences can be a strong factor motivating behaviors such as mitigating climate change (Weber 2006; Marx et al. 2007) and accepting gene technology (Connor and Siegrist 2010). Given the magnitude of invasive species in Indiana (IN Invasive Species Task Force 2008), many land managers have experienced the ramifications of invasive exotic species first-hand in their work (Ma et al. 2018). As such, studies documenting ecological impacts of hybrid trees combined with land managers' own experiences with invasive exotic species may be important in shaping land managers' perceptions of hybrid trees, particularly their potential ecological impacts.

In this context, however, our results also suggest that land manager acceptance of hybrid and GM trees will likely involve careful consideration of potential utility in light of possible risk as new information becomes available. Specifically, land managers may consider some risks, such as species extinction or not meeting the production demands of a growing population, as more important than those associated with the use of hybrid (Fig. 2) and GM trees (Fig. 4). Our study also identifies a high percentage of land managers expressing neutrality or "don't know" (Figs. 1-4) about concerns and risks associated with hybrid and GM trees. It was repeatedly conveyed through the preliminary interviews and many comments at the end of the survey, that one way to address land manager concerns about mitigating ecological risk would be for extensive, long-term research and testing to measure what is currently unknown. This is consistent with St-Laurent et al. (2018) regarding the use of assisted migration, where respondents indicated a high degree of uncertainty and need for additional research. These calls for extensive research and evaluation may indicate trust placed in scientists and researchers by land managers, and moving forward, the importance of ecological studies of hybrid and GM trees, rather than an emphasis on items such as cost and availability, which land managers expressed less concern about.

\section{Perceived advantages and attitudes towards using hybrid and GM trees for various purposes}

Land managers shared a high level of agreement that both hybrid (Fig. 1a) and GM trees (Fig. 3a) have tree improvement advantages, such as "greater stress and pest resistance" and "improved tree growth and production". Simultaneously, many land managers felt neutral about various other tree improvement advantages of hybrid and GM trees. This could possibly be due to the still infant nature of the biotechnologies and that land managers may simply not have enough information to form an opinion. In terms of using hybrid and GM trees for various purposes, however, our study shows a high level of agreement with using both tree types for "non-timber production (fruit, syrup, etc.)", "timber production", and "conservation and restoration of at-risk species", and a lowlevel agreement with using them for "promoting biodiversity" and "reforestation and restoration of forests". Our results are consistent with Jepson and Arakelyan (2017a, b), who found that informed and general publics tended to rank the use of both hybrid and GM trees for ash restoration very closely. Interestingly, the purpose of "conservation and restoration of at-risk species" ranked number one in agreement for GM tree use but was third for hybrid trees. Genetic modification of endangered trees, such as the American chestnut, thus far has only involved changing one or a few genes (Jacobs et al. 2013); however, thousands of genes will be different from the conservation target species in a hybrid plant (Häggman et al. 2016). For example, although the total number of 
genes in American chestnut is unknown, 37,000 genes is a good estimate based on data from Chinese chestnut, Castanea mollissima Blume (Xing et al. 2019). Consequently, about 2,300 non-native genes reside in the current 15/16 American chestnut backcross hybrid with Chinese chestnut. The functions and traits controlled by each of those genes is largely unknown, leading to this survey comment (respondent \#152):

One of the biggest concerns and hold-ups, at least for me, is the philosophical question of whether or not a hybrid (American x Chinese chestnut backcross, for example) is truly an equivalent replacement for the at risk native. Even a 15/16 native hybrid has considerable genetic "wiggle room." There are concerns over creating new invasive species, diluting what little remaining pure genetic stock there may be, and overlooking more difficult to determine things such as microbiological and insect interactions with plants.

Further, with at-risk species conservation, the functions and traits of that species in its native ecosystem are being conserved as well (Thomas et al. 2014), as demonstrated in this comment (respondent \#26):

Hybrid trees should be avoided, including their use in proximity to related native trees (to avoid genetic swamping). If in genetic engineering a particular gene can be precisely modified to prevent sensitivity of the tree species to exotic pathogens, it might be acceptable if it can be shown that the modified tree species bears no changes in morphology and "behavior" in the natural landscape. Micro-surgical genetic changes to a species appears to be much better than hybridization, especially with exotic species, e.g., Chinese/American chestnut crosses.

While species conservation was rated in the top three uses for both hybrid (Fig. 2) and GM tree types (Fig. 4), the larger magnitude of non-native genes in a hybrid could be perceived by land managers as a slightly greater risk to an ecosystem than using GM trees, resulting in the somewhat different rankings.

Land managers disagree about using hybrid (Fig. 2) and GM trees (Fig. 4) for "promoting biodiversity" and "reforestation and restoration of forests" because they might perceive these two purposes as being more readily accomplished by existing conventional tree improvement and planting techniques. Traditional tree management methods have widely been perceived as more acceptable and less risky than use of newer biotechnologies by both informed (Jepson and Arakelyan 2017a) and general publics (Hajjar et al. 2014; Hajjar and Kozak 2015; Jepson and Arakelyan 2017a, b; St-Laurent et al. 2018). Further, traditional breeding, silvicultural, and replanting methods have already shown success in many situations for restoring forests and promoting biodiversity (ex: Sweeney et al. 2002; Stanturf et al. 2014; da Cruz et al. 2020). However, when it comes to saving at-risk tree species from new and swift-acting threats such as invasive pests and diseases, traditional breeding that does not use interspecific hybrids or GM trees, has not shown sufficient success to save species, such as American chestnut (Jacobs et al. 2013) and butternut (Pike et al. 2020). As such, land managers might have to navigate between using conventional methods to foster a healthy, diverse forest, such as replanting in more suitable sites, and using new biotechnologies to save species from swift, new threats in their work. It may be helpful for researchers and extension professionals to provide side-by-side comparisons of the timelines, development, implementation, and effects of different techniques and technologies available in order to help land managers decide the best courses of action to follow in their work. 


\section{The effect of land manager characteristics in shaping their perceptions}

Overall, younger land managers were more willing than older land managers to accept newer (i.e., genetic modification) rather than older (i.e., hybridization) technologies (Tables 3, 6, and S3). In relation to ash tree conservation in the UK, Jepson and Arakalyan (2017a, b) found that younger generations not only viewed GM technology more positively than older generations, but also had greater support for methods that involved higher degrees of scientific intervention in general. While St-Laurent et al. (2018) also found a similar age tendency in terms of the use of GM technology as a climate change forest adaptation strategy, Hajjar et al. (2014) did not. However, decreasing acceptance with increasing age has been reported in several studies related to GM food (Hallman et al. 2003; Onyango and Nayga 2004; Schläpfer 2008). Further, not only is this age trend observed with biotechnologies related to plants, but it is also mirrored more broadly in perceptions to other types of technologies (Kwateng et al. 2019; Morris and Venkatesh 2000). However, it should be noted that age was not a significant predictor of current use of hybrid trees in our study, so perception differences by age may not translate to actual use of GM trees either (if/when they are legally allowed to be grown widescale).

Self-identifying as female was associated with greater disagreement with using hybrid trees for restoration and supporting ecosystem services purposes (Table 3 ), and female land managers preferred that neither type of hybrid trees (native species $\times$ native species cross or native species $\times$ non-native species cross) be used (Table S4). Interestingly, none of the variables for GM tree perceptions differed significantly by gender (Table 6). These results are comparable to what was found previously. Specifically, in the only two studies that could be referenced evaluating perceptions to both hybrid and GM trees at the same time, Jepson and Arakelyan found either no difference by gender $(2017 \mathrm{a})$ or that males had more acceptance than females for more interventionist approaches, including hybridization and genetic modification (2017b).

Urban land managers had more positive perceptions of using hybrids for regulating and cultural ecosystem services purposes than managers of natural lands (Table 3), and indeed, were also more likely to use hybrid trees (Table 5). Urban land managers are under immense pressure to plant durable and aesthetic trees, while also maintaining biodiversity (Ordóñez and Duinker 2013; Conway and Vecht 2015). These pressures are strongly rooted in past and current experiences where pests decimated populations of common street tree species, such as American elm with Dutch elm disease in the early to mid-1900s (Hubbes 1999) and more recently various ash species (Fraxinus L.) with the emerald ash borer (Poland and McCullough 2006). These events dramatically illustrated the importance of having a diverse urban tree population with increased resiliency and decreased vulnerability to any single threat. This has led to widespread adoption by urban land managers of the 10-20-30 Formula proposed by Santamour (1990), which states that urban forests should contain "no more than $10 \%$ of any single tree species, no more than $20 \%$ of species in any tree genus, and no more than $30 \%$ of species in any tree family." While this rule has been broadly supported in concept, it is difficult to execute in practice (Kendal et al. 2014). Clearly, the need to meet the 10-20-30 Formula requirements (or similar tree diversity metrics), pressure to have tough species that will tolerate difficult urban conditions, ability to fulfill societal needs and functions, and ultimately, species availability from suppliers, all interact to limit the tree species options of urban land managers. Many hybrid tree species have been (and are still 
being) developed specifically to expand the urban tree species selections with increased tolerance to urban conditions and stressors (Bassuk et al. 2009). Thus, it follows that in the current study, urban land managers would both perceive the use of hybrid trees more positively (particularly for urban purposes), as well as use them more often than those who manage natural lands.

While urban land managers tended to perceive hybrids more positively, those managing more natural lands had greater agreement for the use of GM trees for restoration purposes (Table 6). This could relate to the relative percentages of genes from the target native species and non-target species contained within a GM versus hybrid species (as previously discussed in subsection "Perceived advantages and attitudes towards using hybrid and GM trees for various purposes"). In restoration, not only are species being restored, but also the function of the ecosystem (Thomas et al. 2014). Given the higher percentage of genes from the target species contained within a GM version of that species (compared to a hybrid), natural land managers might be considering that the GM tree type would retain a greater amount of its native genome (Häggman et al. 2016), and thus native adaptations.

Organization type was only associated with two variables regarding perceptions of hybrid trees and none regarding perceptions of GM trees. Land managers working in state government organizations used hybrid trees less than those in local government and nonprofit organizations. Additionally, state government land managers expressed significantly more disagreement with the tree improvement advantages of hybrids, and so may see less benefit to their use. Further, according to our survey, Indiana state government land managers predominantly manage natural lands (84\%), compared to those in local government (13\%) and non-profit (55\%) organizations. As discussed previously, respondents managing natural lands had more negative perceptions with the use of hybrid trees, which may explain why state government land managers were then less likely to use hybrid trees.

\section{Perceptions of 'nativeness'}

'Nativeness', or the level of native genes contained within a species, was clearly a concept of importance to most Indiana land managers. Nearly three-quarters of respondents preferred the native species $\times$ native species hybrid type, while none of the respondents indicated preference for the native species $\times$ non-native species hybrid type. For GM trees, the majority (47\%) of land managers felt that a GM version of a native species was no longer native, while $27 \%$ did not know, indicating that nativeness is an issue in which land managers have diverse, and sometimes uncertain, perspectives. In both the hybrid and GM tree nativeness questions, the levels of ecological concerns and agreement with tree improvement advantages played important, but inverse, roles: those having greater ecological concerns and less agreement on advantages preferred neither hybrid type and perceived GM trees as not native. Perceptions of nativeness and naturalness have contributed to forming perceptions of not just GM trees (Hajjar and Kozak 2015; Jepson and Arakelyan 2017b), but also GM food crops (Mielby et al. 2013; Siegrist et al. 2016) and even GM wildlife (Kohl et al. 2019). However, that begs the question: what is "nativeness" and how can it be conceptualized here?

The concept of nativeness, and how to define it, is intriguing in that it is both ecologically and philosophically rooted. For example, consider: what delineates whether a species arrived in a particular geographic location through human intervention, or whether it arrived there on its own? Do species transported by both Indigenous Peoples and by European settlers (for instance), count as native? Because of this complexity, there is considerable discussion and debate on the topic (e.g., Woods and Moriarty 2001; Warren 2007; Knights 2008). Yet, 
there is no single, widely agreed upon definition. In light of the current discussion of hybrid and GM trees, perhaps the most compelling case is that of Woods and Moriarity (2001), who describe five possible criteria for distinguishing native from non-native species, summarized here:

1. The Human Introduction Criterion: whether human activity indirectly or directly introduced a species to the area

2. The Evolutionary Criterion: whether a species originally evolved in the area

3. The Historical Range Criterion: whether a species has historically grown in the area

4. The Degradation Criterion: whether a species degrades and harms the environment of the area

5. The Community Membership Criterion: whether a species is an integrated component of the community or ecosystem of the area

Woods and Moriarity (2001) are clear to state that meeting or not meeting any single criterion does not automatically classify a species as being native or non-native, but rather how a species meets the most applicable cluster of these criteria given its specific circumstance.

To explore this situation for hybrid and GM trees, it might be helpful to consider the perception of nativeness of these tree types on a spectrum. On the more native end, humans are simply modifying a pre-existing species so that the majority of it will still be the same as the unhybridized version, just slightly improved so that it can survive in its changed environment. If viewed from this perspective, hybrid and GM trees would probably meet criteria 1, 2, 3, and 5. Conversely, on the other extreme, the non-native end, simply by the fact that humans intervened to combine part of one species with another to form hybrid and GM trees, we are essentially creating entirely new species - that have no 'track record' in the target restoration area. If viewed from this second perspective, these tree types would certainly not meet criteria 1,2,3, and 5 for nativeness. From either the more native or non-native perspective, it is still unclear whether hybrid and GM trees of at-risk native species fall in or outside of the fourth criterion pertaining to degradation. As discussed previously, unintentional hybridization of native with non-native tree species has been documented in many instances as being ecologically detrimental (e.g., Burgess and Husband 2006; Culley and Hardiman 2007; Zalapa et al. 2009). However, whether that will be the case for the hybrid and GM trees currently in development specifically for species restoration, rather than as an unintended, uncontrolled consequence (i.e., escape from cultivation), is still largely unknown. Further, the goal of using either hybrid or GM trees for restoration is actually to support ecosystems through reintroduction of a declining species, thus meeting the fourth criterion - but again, whether that goal will be met or not is still to be determined. In our study, land managers expressed strong ecological concerns about hybrid and GM trees which were also associated with their perceptions of nativeness. Thus, to aid in nativeness determinations, more research is needed on the ecological consequences to using hybrid and GM trees developed specifically for restoration and particularly whether they degrade or support their ecosystem.

\section{Conclusion}

The goal of this research was not to make a judgement as to whether hybrid or GM trees should be used. What it does is provide insights into who Indiana land managers are, their perceptions to these tree types, and thus how researchers could engage with land managers 
in building and acting on recommendations on hybrid and GM tree use. Respondents' strongest concern with these tree types was overwhelmingly about the potential for invasiveness, and all ecological concerns were stronger than economic concerns. Respondents agreed most with using hybrid and GM trees for conservation and restoration of at-risk species, timber production, and non-timber products (fruit, syrup, etc.) and disagreed most with using them for promoting biodiversity and reforestation and restoration of forests. We also found that perceptions were not uniform and varied by several land manager characteristics, such as their concerns, age, and type of land managed. While greater ecological concern was negatively associated with current hybrid use, economic concerns did not significantly predict use. Based on the differences seen in this study between urban and natural land managers, further investigation is also required to understand how a land manager's specific work purpose shapes their perceptions and use of hybrids and GM trees. Additionally, given how heavily agrarian the state of Indiana is, future research should explore perceptions of different land manager populations and in other parts of the US and world where land may be used and valued differently.

Overall, the majority of land managers in our study agreed with a variety of advantages and purposes of use for hybrid and GM trees compared to disagreement or neutrality. Thus, if or when using these tree types are deemed an appropriate choice for restoring at-risk species (and approved legally), most land managers in Indiana might be agreeable to recommendations from researchers about using these tree types. It was also made very clear throughout the study that despite indicating a high degree of agreement towards using hybrid and GM trees, land managers still had very strong ecological concerns about their use and suitability as a native replacement. In order to alleviate these concerns, it will be essential that the traits of hybrids and GM trees be thoroughly vetted, particularly ecologically. Land managers have a clear stake in the issue and would ultimately be responsible for any widescale implementation of hybrid and GM trees. It is important for scientists to understand that land managers, as well as other environmental managers, are specialists with pre-existing knowledge and experience with at least some of the issues surrounding hybrid and GM trees and other environmental issues, and have formed a set of values and perceptions around them. Rather than assuming an information deficit, this pre-existing knowledge and set of values should be acknowledged and used as a starting point when scientists engage with land and environmental managers about management decisions in a rapidly changing world (Nisbet and Scheufele 2009). Further, researchers evaluating hybrid and GM trees should not only clearly and regularly communicate the results and recommendations from their work after completing a project, but seek to engage, consult, and co-generate ideas and solutions with land managers, environmental managers, and other stakeholders from the beginning. This can provide useful direction for research projects, such as identification of key tree traits and areas of concern to focus on that might not be as readily apparent to scientists who often work in more controlled, smaller scale settings. Ultimately, inclusion of land managers in the research process will also build greater ownership and involvement, and thus, greater success for hybrid and GM tree research and its applications.

Supplementary Information The online version contains supplementary material available at https://doi. org/10.1007/s11056-021-09895-6.

Acknowledgements We would like to extend our sincerest gratitude to all of the Indiana land managers who took the time to be interviewed, provide thoughtful feedback on survey concepts and construction, and take our survey. Many thanks to Lenny Farlee, Carrie Tauscher, Lindsey Purcell, and Bryce Patz for taking the time to help me understand urban land managers in Indiana and construct the survey. Thank you to Dr. 
Mysha Clarke (University of Florida) for helping with interview protocol construction and interview transcription. We would also like to thank many folks at Purdue University: the entire Human Dimensions Lab, Dr. Robert Joly, and Madeline Montague, along with Dr. Sean Hoban at the Morton Arboretum, for piloting the survey and providing feedback. The Purdue University Department of Natural Resources provided funding for this project through the Fred M. van Eck Scholarship.

Authors' contributions Conceptualization: Andrea N. Brennan, Zhao Ma, Douglass F. Jacobs; Methodology: Andrea N. Brennan, Zhao Ma; Formal analysis and investigation: Andrea N. Brennan, Zhao Ma; Writing —original draft preparation: Andrea N. Brennan; Writing-review and editing: Andrea N. Brennan, Zhao Ma, Douglass F. Jacobs; Funding acquisition: Andrea N. Brennan; Supervision: Zhao Ma, Douglass F. Jacobs.

Funding This work was supported by the Department of Forestry and Natural Resources, Purdue University (Fred M. van Eck Scholarship to A.B.).

Availability of data and material The datasets generated during and/or analyzed during the current study are not publicly available as the data are sensitive; all data are human subject data with extensive identifiable demographic information. The data are available from the corresponding author upon reasonable request from qualified researchers.

\section{Declarations}

Conflicts of interest The authors declare that they have no conflicts of interest.

Code availability The novel code generated for this study is available from the corresponding author upon reasonable request.

Ethical approval Prior to implementation, the interview and survey recruiting emails, interview protocol, and survey questionnaire were approved by Purdue University's Institutional Review Board (protocol no. 1805020620).

Consent to participate Participation in this study was entirely voluntary, as indicated in the recruiting email approved by Purdue University's Institutional Review Board.

Consent for publication All authors gave their informed consent to this publication and its content.

Open Access This article is licensed under a Creative Commons Attribution 4.0 International License, which permits use, sharing, adaptation, distribution and reproduction in any medium or format, as long as you give appropriate credit to the original author(s) and the source, provide a link to the Creative Commons licence, and indicate if changes were made. The images or other third party material in this article are included in the article's Creative Commons licence, unless indicated otherwise in a credit line to the material. If material is not included in the article's Creative Commons licence and your intended use is not permitted by statutory regulation or exceeds the permitted use, you will need to obtain permission directly from the copyright holder. To view a copy of this licence, visit http://creativecommons.org/licenses/by/4.0/.

\section{References}

Allendorf FW, Luikart G, Aitken SN (2013) Hybridization. Conservation and the Genetics of Populations, 2nd edn. Wiley-Blackwell, Chichester, pp 352-376

Bassuk N, Curtis DF, Marranca BZ, Neal B (2009) Recommended urban trees: Site assessment and tree selection for stress tolerance. Ithaca, NY

Bellard C, Cassey P, Blackburn TM (2016) Alien species as a driver of recent extinctions. Biol Lett 12:1-4. https://doi.org/10.1098/rsbl.2015.0623

Brennan AN, McKenna JR, Hoban SM, Jacobs DF (2020) Hybrid breeding for restoration of threatened forest trees: Evidence for incorporating disease tolerance in Juglans cinerea. Front Plant Sci 11:580693. https://doi.org/10.3389/fpls.2020.580693 
Burgess KS, Husband BC (2006) Habitat differentiation and the ecological costs of hybridization: The effects of introduced mulberry (Morus alba) on a native congener (M. rubra). J Ecol 94:1061-1069. https://doi.org/10.1111/j.1365-2745.2006.01152.x

Butler BJ, Hewes JH, Dickinson BJ et al (2016) Family forest ownerships of the United States, 2013: Findings from the USDA Forest Service's National Woodland Owner Survey. J for 114:638-647. https:// doi.org/10.5849/jof.15-099

Christensen RHB (2019) ordinal-Regression Models for Ordinal Data

Clark SL, Schlarbaum SE, Saxton AM, Baird R (2019) Eight-year blight (Cryphonectria parasitica) resistance of backcross-generation American chestnuts (Castanea dentata) planted in the southeastern United States. For Ecol Manage 433:153-161. https://doi.org/10.1016/j.foreco.2018.10.060

Connor M, Siegrist M (2010) Factors influencing people's acceptance of gene technology: The role of knowledge, health expectations, naturalness, and social trust. Sci Commun 32:514-538. https://doi. org/10.1177/1075547009358919

Conway TM, Vecht JV (2015) Growing a diverse urban forest: Species selection decisions by practitioners planting and supplying trees. Landsc Urban Plan 138:1-10. https://doi.org/10.1016/j.landu rbplan.2015.01.007

Costa-Font M, Gil JM, Traill WB (2008) Consumer acceptance, valuation of and attitudes towards genetically modified food: Review and implications for food policy. Food Policy 33:99-111. https:// doi.org/10.1016/j.foodpol.2007.07.002

Cronbach LJ (1951) Coefficient alpha and the internal structure of tests. Psychometrika 16:297-334

Cronk QC, Suarez-Gonzalez A (2018) The role of interspecific hybridization in adaptive potential at range margins. Mol Ecol 27:4653-4656. https://doi.org/10.1111/mec.14927

Culley TM, Hardiman NA (2007) The beginning of a new invasive plant: a history of the ornamental Callery pear in the United States. Bioscience 57:956-964

da Cruz DC, Benayas JMR, Ferreira GC, Ribeiro SS (2020) Tree communities in three-year-old postmining sites under different forest restoration techniques in the Brazilian Amazon. Forests. https:// doi.org/10.3390/F11050527

Dillman DA, Smyth JD, Christian LM (2014) Internet, mail, and mixed-mode surveys: the tailored design method, 4th edn. Wiley, Hoboken, NJ

Diskin M, Steiner KC, Hebard FV (2006) Recovery of American chestnut characteristics following hybridization and backcross breeding to restore blight-ravaged Castanea dentata. For Ecol Manage 223:439-447. https://doi.org/10.1016/j.foreco.2005.12.022

FAO (2010) Forests and Genetically Modified Trees. Food and Agriculture Organization of the United Nations, Rome

Fernandez-Cornejo J, Caswell M, Klotz-Ingram C (1999) Seeds of change: From hybrids to genetically modified crops. Choices 14:18-22

Fernihough A, Henningsen A (2019) mfx: Marginal Effects, Odds Ratios and Incidence Rate Ratios for GLMs

Fischhoff B, Fischhoff I (2001) Publics' opinions about biotechnologies. AgBioforum 4:155-162

Fox J, Weisberg S (2019) An R Companion to Applied Regression, 3rd edn. Sage, Thousand Oaks, CA

Frewer LJ, van der Lans IA, Fischer ARH et al (2013) Public perceptions of agri-food applications of genetic modification: a systematic review and meta-analysis. Trends Food Sci Technol 30:142-152. https://doi.org/10.1016/j.tifs.2013.01.003

Gamborg C, Sandøe P (2010) Ethical considerations regarding genetically modified trees. Forests and genetically modified trees. Food and Agriculture Organization of the United Nations, Rome, pp $163-175$

Gaskin JF (2016) The role of hybridization in facilitating tree invasion. AoB Plants 9(1):plw079. https:// doi.org/10.1093/aobpla/plw079

Grimes DA, Schulz KF (2002) Descriptive studies: What they can and cannot do. Lancet 359:145-149. https://doi.org/10.1016/S0140-6736(02)07373-7

Groves RM (2006) Nonresponse rates and nonresponse bias in household surveys. Public Opin Q 70(5):646-675. https://doi.org/10.1093/poq/nfl033

Groves RM, Peytcheva E (2008) The impact of nonresponse rates on nonresponse bias. Public Opin Q 72(2):167-189. https://doi.org/10.1093/poq/nfn011

Häggman H, Sutela S, Fladung M (2016) Genetic engineering contribution to forest tree breeding efforts. In: Cristina V, Gallardo F, Häggman H et al (eds) Biosafety of Forest Transgenic Trees. Springer, Dordrecht, pp 11-29

Hajjar R, Kozak RA (2015) Exploring public perceptions of forest adaptation strategies in Western Canada: implications for policy-makers. For Policy Econ 61:59-69. https://doi.org/10.1016/j.forpol. 2015.08.004 
Hajjar R, Mcguigan E, Moshofsky M, Kozak RA (2014) Opinions on strategies for forest adaptation to future climate conditions in western Canada: surveys of the general public and leaders of forestdependent communities. Can J for Res 44:1525-1533. https://doi.org/10.1139/cjfr-2014-0142

Hall C (2007) GM technology in forestry: Lessons from the GM food "debate." Int J Biotechnol 9:436-447

Hallman WK, Hebden WC, Aquino HL, et al (2003) Public perceptions of genetically-modified foods: a national study of American knowledge and opinion. (Publication number RR1003-004). New Brunswick, NJ

Harfouche A, Meilan R, Kirst M et al (2012) Accelerating the domestication of forest trees in a changing world. Trends Plant Sci 17:64-72. https://doi.org/10.1016/j.tplants.2011.11.005

Hervé M (2020) RVAideMemoire: testing and plotting procedures for biostatistics

Hubbes M (1999) The American elm and Dutch elm disease. For Chron 75:265-273. https://doi.org/10. $5558 / \mathrm{tfc} 75265-2$

IN Invasive Species Task Force (2008) At the crossroads-invasive species in Indiana: findings and recommendations from the Indiana invasive species task force. Indianapolis, IN

Jacobs DF, Dalgleish HJ, Nelson CD (2013) A conceptual framework for restoration of threatened plants: the effective model of American chestnut (Castanea dentata) reintroduction. New Phytol 197:378-393

Jepson P, Arakelyan I (2017a) Developing publicly acceptable tree health policy: public perceptions of treebreeding solutions to ash dieback among interested publics in the UK. For Policy Econ 80:167-177. https://doi.org/10.1016/j.forpol.2017.03.002

Jepson P, Arakelyan I (2017b) Exploring public perceptions of solutions to tree diseases in the UK: implications for policy-makers. Environ Sci Policy 76:70-77. https://doi.org/10.1016/j.envsci.2017.06.008

Kendal D, Dobbs C, Lohr VI (2014) Global patterns of diversity in the urban forest: Is there evidence to support the 10/20/30 rule? Urban for Urban Green 13:411-417. https://doi.org/10.1016/j.ufug.2014. 04.004

Kilgore MA, Snyder SA, Eryilmaz D et al (2015) Assessing the relationship between different forms of landowner assistance and family forest owner behaviors and intentions. J for 113:12-19. https://doi. org/10.5849/jof.13-059

Knapp BO, Wang GG, Clark SL et al (2014) Leaf physiology and morphology of Castanea dentata (Marsh.) Borkh., Castanea mollissima Blume, and three backcross breeding generations planted in the southern appalachians, USA. New for 45:283-293. https://doi.org/10.1007/s11056-014-9408-X

Knights P (2008) Native species, human communities and cultural relationships. Environ Values 17:353373. https://doi.org/10.3197/096327108X343121

Knupfer N, McLellan H (1996) Descriptive research methodologies. In: Jonassen D (ed) Handbook of Research for Educational Communications and Technology. Lawrence Erlbaum Associates, New York, NY, pp 1196-1212

Kohl PA, Brossard D, Scheufele DA, Xenos MA (2019) Public views about gene editing wildlife for conservation. Conserv Biol. https://doi.org/10.1111/cobi.13310

Kwateng KO, Atiemo KAO, Appiah C (2019) Acceptance and use of mobile banking: an application of UTAUT2. J Enterp Inf Manag 32:118-151. https://doi.org/10.1108/JEIM-03-2018-0055

Ma Z, Clarke M, Church SP (2018) Insights into individual and cooperative invasive plant management on family forestlands. Land Use Policy 75:682-693. https://doi.org/10.1016/j.landusepol.2018.02.010

Martín JA, Sobrino-Plata J, Rodríguez-Calcerrada J et al (2019) Breeding and scientific advances in the fight against Dutch elm disease: Will they allow the use of elms in forest restoration? New for 50:183215. https://doi.org/10.1007/s11056-018-9640-x

Marx SM, Weber EU, Orlove BS et al (2007) Communication and mental processes: experiential and analytic processing of uncertain climate information. Glob Environ Chang 17:47-58. https://doi.org/10. 1016/j.gloenvcha.2006.10.004

Merkle SA, Andrade GM, Nairn CJ et al (2007) Restoration of threatened species: a noble cause for transgenic trees. Tree Genet Genomes 3:111-118. https://doi.org/10.1007/s11295-006-0050-4

Mielby H, Sandøe P, Lassen J (2012) The role of scientific knowledge in shaping public attitudes to GM technologies. Public Underst Sci 22:155-168

Mielby H, Sandøe P, Lassen J (2013) Multiple aspects of unnaturalness: Are cisgenic crops perceived as being more natural and more acceptable than transgenic crops? Agric Human Values 30:471-480. https://doi.org/10.1007/s10460-013-9430-1

Millennium Ecosystem Assessment (2005) Ecosystems and human well-being: Synthesis. Island Press, Washington, DC

Morris MG, Venkatesh V (2000) Age differences in technology adoption decisions: implications for a changing work force. Pers Psychol 53:375-403 
NASEM (2019) Forest Health and Biotechnology. National Academies of Sciences, Engineering, and Medicine. National Academies Press, Washington, D.C.

Nisbet M, Scheufele D (2009) What's next for science communication? Promising directions and lingering distractions. Amer J Bot 96(10):1767-1778. https://doi.org/10.3732/ajb.0900041

Niu S, Luo Y, Li D et al (2014) Plant growth and mortality under climatic extremes: an overview. Environ Exp Bot 98:13-19. https://doi.org/10.1016/j.envexpbot.2013.10.004

NRCS (2020) Native, invasive, and other plant-related definitions. In: Nat. Resour. Conserv. Serv. https:// www.nrcs.usda.gov/wps/portal/nrcs/detail/ct/technical/ecoscience/invasive/?cid=nrcs142p2_011124. Accessed 5 Aug 2020

Nunnally JC (1978) Psychometric Theory, 2nd edn. McGraw-Hill, New York, NY

Onyango BM, Nayga RM (2004) Consumer acceptance of nutritionally enhanced genetically modified food: relevance of gene transfer technology. J Agric Resour Econ 29:567-583

Ordóñez C, Duinker PN (2013) An analysis of urban forest management plans in Canada: implications for urban forest management. Landsc Urban Plan 116:36-47. https://doi.org/10.1016/j.landurbplan. 2013.04.007

Parker IM, Gilbert GS (2004) The evolutionary ecology of novel plant-pathogen interactions. Annu Rev Ecol Evol Syst 35:675-700. https://doi.org/10.1146/annurev.ecolsys.34.011802.132339

Pike CC, Williams M, Brennan A, et al (2020) Save our species: a blueprint for restoring butternut (Juglans cinerea) across eastern North America. J For fvaa053:. https://doi.org/10.1093/jofore/fvaa053

Pinchot CC, Flower CE, Knight KS, et al (2017) Development of new Dutch elm disease-tolerant selection for restoration of the American elm in urban and forested landscapes. In: Sneizko RA, Man G, Hiokins V, et al. (eds) Gene conservation of tree species-banking on the future. U.S. Department of Agriculture, Forest Service, Pacific Northwest Research Station, Portland, OR, pp 53-63

Poland TM, McCullough DG (2006) Emerald ash borer: Invasion of the urban forest and the threat to North America's ash resource. J for 104:118-124. https://doi.org/10.1093/jof/104.3.118

R Core Team (2019) R: A language and environment for statistical computing. R Foundation for Statistical Computing, Vienna, Austria

Santamour FS (1990) Trees for urban planting: Diversity, uniformity, and common sense. In: Proceedings of the Seventh Conference of the Metropolitan Tree Improvement Alliance (METRIA). The Morton Arboretum, Lisle, IL, pp 57-65

Schläpfer F (2008) Determinants of voter support for a 5-year ban on the cultivation of genetically modified crops in Switzerland. J Agric Econ 59:421-435. https://doi.org/10.3929/ethz-a-005717544

Sedjo R (2010) Social, legal and regulatory issues related to transgenic trees. Forests and Genetically Modified Trees. Food and Agriculture Organization of the United Nations, Rome, pp 203-216

Siegrist M, Hartmann C, Sütterlin B (2016) Biased perception about gene technology: How perceived naturalness and affect distort benefit perception. Appetite 96:509-516. https://doi.org/10.1016/j. appet.2015.10.021

Spector P (1992) Summated rating scale construction. Sage Publications, Newbury Park, CA

Stanturf JA, Palik BJ, Dumroese RK (2014) Contemporary forest restoration: a review emphasizing function. For Ecol Manage 331:292-323. https://doi.org/10.1016/j.foreco.2014.07.029

St-Laurent GP, Hagerman S, Kozak R (2018) What risks matter? Public views about assisted migration and other climate-adaptive reforestation strategies. Clim Change 151:573-587. https://doi.org/10. 1007/s10584-018-2310-3

Strauss SH, Schmitt M, Sedjo R (2009) Forest scientist views of regulatory obstacles to research and development of transgenic forest biotechnology. J for 107:350-357

Sweeney BW, Czapka SJ, Yerkes T (2002) Riparian forest restoration: increasing success by reducing plant competition and herbivory. Restor Ecol 10:392-400

Thomas CD, Cameron A, Green RE et al (2004) Extinction risk from climate change. Nature 427:145148. https://doi.org/10.1038/nature02121

Thomas E, Jalonen R, Loo J, et al (2014) Genetic considerations in ecosystem restoration using native tree species. The state of the world's forest genetic resources - Thematic study. FAO and Bioversity International, Rome, Italy

Todesco M, Pascual MA, Owens GL et al (2016) Hybridization and extinction. Evol Appl 9:892-908. https://doi.org/10.1111/eva.12367

Tsatsakis AM, Nawaz MA, Kouretas D et al (2017) Environmental impacts of genetically modified plants: a review. Environ Res 156:818-833. https://doi.org/10.1016/j.envres.2017.03.011

USGS (2020) What are the differences between endangered, threatened, imperiled, and at-risk species? In: U.S. Geol. Surv. https://www.usgs.gov/faqs/what-are-differences-between-endangered-threa tened-imperiled-and-risk-species? Accessed 5 Aug 2020 
Vila M, Weber E, D'Antonio CM (2000) Conservation implications of invasion by plant hybridization. Biol Invasions 2:207-217

Walter C, Menzies M (2010) Genetic modification as a component of forest biotechnology. In: Forests and genetically modified trees. Food and Agriculture Organization of the United Nations, Rome, Italy, pp 3-17

Warren CR (2007) Perspectives on the "alien" versus "native" species debate: A critique of concepts, language and practice. Prog Hum Geogr 31:427-446. https://doi.org/10.1177/0309132507079499

Weber EU (2006) Experience-based and description-based perceptions of long-term risk: Why global warming does not scare us (yet). Clim Change 77:103-120. https://doi.org/10.1007/ s10584-006-9060-3

Williams C (2005) Framing the issues on transgenic forests. Nat Biotechnol 23:530-532

Woods M, Moriarty PV (2001) Strangers in a strange land: The problem of exotic species. Environ Values 10:163-191

Xing Y, Liu Y, Zhang Q et al (2019) Hybrid de novo genome assembly of Chinese chestnut (Castanea mollissima). Gigascience 8:1-7. https://doi.org/10.1093/gigascience/giz112

Zalapa JE, Brunet J, Guries RP (2009) Patterns of hybridization and introgression between invasive Ulmus pumila (Ulmaceae) and native U. rubra. Am J Bot 96:1116-1128. https://doi.org/10.3732/ajb.0800334

Publisher's Note Springer Nature remains neutral with regard to jurisdictional claims in published maps and institutional affiliations. 